\title{
Role of Mitogen-Activated Protein Kinase Activation in Injured and Intact Primary Afferent Neurons for Mechanical and Heat Hypersensitivity after Spinal Nerve Ligation
}

\author{
Koichi Obata, Hiroki Yamanaka, Kimiko Kobayashi, Yi Dai, Toshiyuki Mizushima, Hirokazu Katsura, Tetsuo Fukuoka, \\ Atsushi Tokunaga, and Koichi Noguchi \\ Department of Anatomy and Neuroscience, Hyogo College of Medicine, Hyogo 663-8501, Japan
}

\begin{abstract}
To investigate whether activation of mitogen-activated protein kinase (MAPK) in damaged and/or undamaged primary afferents participates in neuropathic pain after partial nerve injury, we examined the phosphorylation of extracellular signal-regulated protein kinase (ERK), p38 MAPK, and c-Jun N-terminal kinase (JNK) in the L4 and L5 dorsal root ganglion (DRG) in the L5 spinal nerve ligation (SNL) model. We first confirmed, using activating transcription factor 3 and neuropeptide Y immunoreactivity, that virtually all L4 DRG neurons are spared from axotomy in this model. In the injured L5 DRG, the L5 SNL induced the activation of ERK, p38, and JNK in different populations of DRG neurons. In contrast, in the uninjured L4 DRG, the L5 SNL induced only p38 activation in tyrosine kinase A-expressing small- to medium-diameter neurons. Intrathecal ERK, p38, and JNK inhibitor infusions reversed SNL-induced mechanical allodynia, whereas only p38 inhibitor application attenuated SNL-induced thermal hyperalgesia. Furthermore, the L5 dorsal rhizotomy did not prevent SNL-induced thermal hyperalgesia. We therefore hypothesized that p38 activation in the uninjured L4 DRG might be involved in the development of heat hypersensitivity in the L5 SNL model. In fact, the treatment of the p38 inhibitor and also anti-nerve growth factor reduced SNL-induced upregulation of brain-derived neurotrophic factor and transient receptor potential vanilloid type 1 expression in the L4 DRG. Together, our results demonstrate that the L5 SNL induces differential activation of MAPK in injured and uninjured DRG neurons and, furthermore, that MAPK activation in the primary afferents may participate in generating pain hypersensitivity after partial nerve injury.
\end{abstract}

Key words: extracellular signal-regulated protein kinase; 38 mitogen-activated protein kinase; c-Jun N-terminal kinase/stress-activated protein kinase; brain-derived neurotrophic factor; TRPV1; neuropathic pain

\section{Introduction}

Peripheral nerve injury often results in spontaneous pain sensation, hyperalgesia, and allodynia, which are associated with neuropathic pain. A number of animal models of chronic pain after nerve injury have been introduced. Chronic constriction injury (CCI) of the sciatic nerve (Bennett and Xie, 1988), partial sciatic nerve ligation (Seltzer et al., 1990), L5 and L6 spinal nerve ligation (SNL) (Kim and Chung, 1992), and spared nerve injury (Decosterd and Woolf, 2000) have been widely used. All of these neuropathic pain models are made by partial nerve injury, in which some primary afferents are axotomized and the others are spared. Among them, the L5 SNL model is unique because the L4 dorsal root ganglion (DRG) neurons are clearly separated from the axotomized L5 DRG neurons. In previous studies, much at-

Received May 20, 2004; revised Sept. 30, 2004; accepted 0ct. 1, 2004

This work was supported in part by grants-in-aid for scientific research and grants from the Open Research Center, Hyogo College of Medicine, and from the Japanese Ministry of Education, Science, and Culture. This work was also supported by a grant-in-aid for researchers from the Hyogo College of Medicine. We thank Yuki Obata and Nobumasa Ushio for technical assistance. We thank Dr. D. A. Thomas for correcting the English usage.

Correspondence should be addressed to Dr. Koichi Noguchi, Department of Anatomy and Neuroscience, Hyogo College of Medicine, 1-1 Mukogawa-cho, Nishinomiya, Hyogo 663-8501, Japan. E-mail: noguchi@hyo-med.ac.jp. DOI:10.1523/JNEUROSCI.3388-04.2004

Copyright $\odot 2004$ Society for Neuroscience $\quad 0270-6474 / 04 / 2410211-12 \$ 15.00 / 0$ tention has been focused on the directly damaged primary afferents and their influence on the activity of dorsal horn neurons. However, there is increasing evidence suggesting that DRG neurons with intact axons also show an alteration of excitability and gene expression, and these changes might have functional roles in neuropathic pain (Ali et al., 1999; Gold, 2000; Michaelis et al., 2000; Wu et al., 2001; Ma et al., 2003; Schafers et al., 2003c). For example, substance $\mathrm{P}(\mathrm{SP})$, calcitonin gene-related peptide (CGRP), brain-derived neurotrophic factor (BDNF), and transient receptor potential vanilloid type 1 (TRPV1) increase in the intact DRG neurons in several neuropathic pain models ( $\mathrm{Ma}$ and Bisby, 1998a,b; Hudson et al., 2001; Fukuoka and Noguchi, 2002).

Mitogen-activated protein kinases (MAPKs) transduce diverse extracellular stimuli to mitogenic and differentiation signals (Lewis et al., 1998; Widmann et al., 1999). The MAPK family includes extracellular signal-regulated protein kinases (ERKs), p38 MAPK, and c-Jun N-terminal kinase/stress-activated protein kinase (JNK/SAPK). Activation of ERK in DRG neurons contributes to pain hypersensitivity by increasing gene transcription, as well as by posttranslational modifications of target proteins (Aley et al., 2001; Averill et al., 2001; Dai et al., 2002; Dina et al., 2003; Obata et al., 2003b). p38 MAPK activation in DRG neurons has 
also been implicated in exaggerated pain states (Ji et al., 2002; Jin et al., 2003; Schafers et al., 2003b). However, there has been no study examining MAPK activation in adjacent uninjured DRG neurons after partial nerve injury. Furthermore, the contribution of JNK activation in sensory neurons to pain is unknown, although peripheral axotomy has been shown to induce JNK/SAPK activation in DRG neurons (Kenney and Kocsis, 1998).

In this study, we precisely identified the axotomized sensory neurons in the L4 and L5 DRG in the L5 SNL model and then set out to investigate whether ERK, p38, and JNK are activated in both damaged and undamaged primary afferents and participate in the development of mechanical and/or heat hypersensitivity. We now show that in the nearby uninjured L4 DRG, the L5 SNL induces activation of $\mathrm{p} 38$ but not ERK or JNK, and, furthermore, this p38 activation regulates BDNF and TRPV1 expression and contributes to thermal hyperalgesia, partially through alterations in the target-derived nerve growth factor (NGF).

\section{Materials and Methods}

Animals. A total of 130 male Sprague Dawley rats weighing 200-250 gm was used. All animal experimental procedures were approved by the Hyogo College of Medicine Committee on Animal Research and were performed in accordance with National Institutes of Health guidelines on animal care.

Surgical procedures. All experimental procedures were done on rats that were deeply anesthetized with sodium pentobarbital $(50 \mathrm{mg} / \mathrm{kg}$, i.p.). Additional doses of the anesthetics were given as needed. In all rats, no surgery was performed on the right side. Special care was taken to prevent infection and to minimize the influence of inflammation. The hair of the rat's lower back and thigh was shaved, and the skin was sterilized with $0.5 \%$ chlorhexidine and covered with clean paper. Sterile operating instruments were used. Rats without surgery $[n=4$ for immunohistochemistry and $n=3$ for reverse transcription (RT)-PCR] were used as naive controls.

To produce an L5 SNL, a skin incision $(3-4 \mathrm{~cm})$ was made in the midline lumbar region (L4-S1). The L6 transverse process was identified, freed of muscular attachments, and partially removed with the help of bone ronguers. This exposed the L 5 spinal nerve. The L5 ventral ramus was isolated, freed from the adjacent nerves, and then the L5 spinal nerve was tightly ligated with silk suture and transected distal to the ligature. After surgery, the wound was washed with saline and closed in layers (fascia and skin) with 3-0 silk thread. Animals were allowed to survive for 3,7 , or $14 \mathrm{~d}$ after surgery $(n=4$ for immunohistochemistry for each time point).

For an additional group of rats that received the L5 SNL and the L4 or L5 dorsal rhizotomy surgery $(n=8)$, hemilaminectomy of the L4 and/or L5 vertebra after a similar skin incision was performed. After opening the dura and arachnoid membranes with a sharp needle, the left L4 or L5 dorsal root was exposed and cut $2-3 \mathrm{~mm}$ proximal to the DRG, and $\sim 2$ $\mathrm{mm}$ of the root was removed, taking care not to damage the ventral root. The distal and proximal stumps of the transected L4 or L5 dorsal root were then gently separated from each other to avoid nerve regeneration between them. Immediately after the L4 or L5 dorsal rhizotomy, the L5 SNL surgery was performed, as described above. Animals were allowed to survive for $14 \mathrm{~d}$ after surgery.

The intrathecal delivery of MAPK inhibitors or anti-NGF was performed basically as described previously (Fukuoka et al., 2001; Obata et al., 2003b). A laminectomy of the L5 vertebra was performed under adequate anesthesia with sodium pentobarbital. The dura was cut, and a soft tube (Silascon; outer diameter, $0.64 \mathrm{~mm}$; Kaneka Medix, Osaka, Japan) was inserted into the subarachnoid space of the spinal cord at the L4/5 DRG level. For sustained intrathecal drug delivery, a mini-osmotic pump (Alzet type 2001; Durect, Cupertino, CA) that operates at a rate of $1 \mu \mathrm{l} / \mathrm{hr}$ for a period of $7 \mathrm{~d}$ was filled with the MAPK kinase (MEK) $1 / 2$ inhibitor 1,4-diamino-2,3-dicyano-1,4-bis(o-aminophenylmercapto) butadiene (U0126; $0.5 \mu \mathrm{g} / \mu \mathrm{l}$; Calbiochem, La Jolla, CA), the p38 inhibitors 4-(4-fluorophenyl)-2-(4-methylsulfinylphenyl)-5-(4-pyridyl) imidazole (SB203580; $0.5 \mu \mathrm{g} / \mu \mathrm{l}$; Calbiochem) and FR167653 (10 or 50 $\mu \mathrm{g} / \mu \mathrm{l}$; a gift from Fujisawa Pharmaceutical, Osaka, Japan), the JNK inhibitor anthra[1,9-cd]pyrazol-6(2H)-one (SP600125; $2.5 \mu \mathrm{g} / \mu \mathrm{l}$; Calbiochem), in 50\% DMSO, or sheep anti-NGF antibody ( $1 \mu \mathrm{g} / \mu \mathrm{l}$; Chemicon, Temecula, CA), in normal saline. The catheter of the pump was implanted intrathecally at least $3 \mathrm{hr}$ before the L5 SNL. DMSO (50\%) or normal saline was used as the vehicle control. Rats were allowed to survive for up to $7 \mathrm{~d}$ after surgery [ $n=4$ for immunohistochemistry; $n=4$ for in situ hybridization histochemistry (ISHH); $n=3$ for RT-PCR].

The local application of anti-NGF was performed basically as described previously (Fukuoka et al., 2001). A soft tube (Silascon; outer diameter, $0.64 \mathrm{~mm}$; Kaneka Medix) was placed on the surface of the L4 spinal nerve. For sustained peripheral drug delivery, a mini-osmotic pump (Alzet type 2001; Durect) that operates at a rate of $1 \mu \mathrm{l} / \mathrm{hr}$ for a period of $7 \mathrm{~d}$ was filled with sheep anti-NGF antibody $(1 \mu \mathrm{g} / \mu \mathrm{l}$; Chemicon), in normal saline. The catheter of the pump was implanted at least $3 \mathrm{hr}$ before the L5 SNL. Normal saline was used as the vehicle control. Rats were allowed to survive for up to $7 \mathrm{~d}$ after surgery $(n=4$ for immunohistochemistry).

Behavioral tests. All rats were tested for mechanical allodynia and thermal hyperalgesia of the plantar surface of the hindpaw $1 \mathrm{~d}$ before surgery and 3, 7, or $14 \mathrm{~d}$ after surgery. Mechanical allodynia was assessed with a dynamic plantar aesthesiometer (Ugo Basile, Comerio, Italy), which is an automated von Frey-type system (Kalmar et al., 2003; Lever et al., 2003). To measure rat hindpaw mechanical thresholds, rats were placed in plastic cages with a wire mesh floor and allowed to acclimate for $15 \mathrm{~min}$ before each test session. A paw-flick response was elicited by applying an increasing force (measured in grams) using a plastic filament $(0.5 \mathrm{~mm}$ diameter) focused on the middle of the plantar surface of the ipsilateral hindpaw. The force applied was initially below detection threshold, increased from 1 to $50 \mathrm{gm}$ in $1 \mathrm{gm}$ steps over $20 \mathrm{sec}$, and was then held at 50 $\mathrm{gm}$ for an additional $10 \mathrm{sec}$. The rate of force increase was $2.5 \mathrm{gm} / \mathrm{sec}$. The force applied to elicit a reflex removal of the ipsilateral hindpaw was monitored. This was defined as the mean of three measurements at $1 \mathrm{~min}$ intervals. The variability between trials was $\sim 2 \mathrm{gm}$.

Heat hypersensitivity was tested using the plantar test (7370; Ugo Basile). A radiant heat source beneath a glass floor was aimed at the plantar surface of the hindpaw. Three measurements of latency were taken for each hindpaw in each test session. The hindpaws were tested alternately, with intervals between consecutive tests of $>5 \mathrm{~min}$. The three measurements of latency per side were averaged, and a difference score was computed by subtracting the average latency of the contralateral side from that of the ipsilateral side. Negative difference scores indicated a hyperalgesic response on the ipsilateral side. An assistant who was unaware of the treatment group performed all of the behavioral experiments.

Data are expressed as mean \pm SEM. Differences in changes of values over time of each group were tested using one-way ANOVA, followed by individual post hoc comparisons (Fisher's exact test). One-way ANOVA, followed by individual post hoc comparisons (Fisher's exact test) or pairwise comparisons ( $t$ test), was used to assess differences of values between the intrathecal groups. A difference was accepted as significant if $p<0.05$.

Immunohistochemistry. The rats were deeply anesthetized with sodium pentobarbital and perfused transcardially with $1 \%$ paraformaldehyde in $0.1 \mathrm{~m}$ phosphate buffer ( $\mathrm{PB}), \mathrm{pH} 7.4$, followed by $4 \%$ paraformaldehyde in $0.1 \mathrm{M}$ PB 3,7 , or $14 \mathrm{~d}$ after surgery ( $n=4$ at each time point). The left L4/5 DRGs were dissected out and processed for phosphorylated-ERK (p-ERK) 1/2, p-p38, p-SAPK/JNK, activating transcription factor 3 (ATF3), neuropeptide Y (NPY), neurofilament (NF) 200, glial fibrillary acid protein (GFAP), tyrosine kinase (trk) A, BDNF, and TRPV1 immunohistochemistry according to the procedure used in our previous study (Noguchi et al., 1995). The polyclonal primary antibody for p-ERK1/2 (1:400; Cell Signaling Technology, Beverly, MA), p-p38 (1:400; Cell Signaling Technology), p-SAPK/JNK (1:400; Cell Signaling Technology), ATF3 (1:200; Santa Cruz Biotechnology, Santa Cruz, CA), NPY (1:2000; Amersham Biosciences, Little Chalfont, UK), GFAP (1:400; Dako, Glostrup, Denmark), trkA (1:500; Chemicon), BDNF (1:400; Chemicon), and TRPV1 (1:400; Oncogene, San Diego, CA) and the monoclonal 


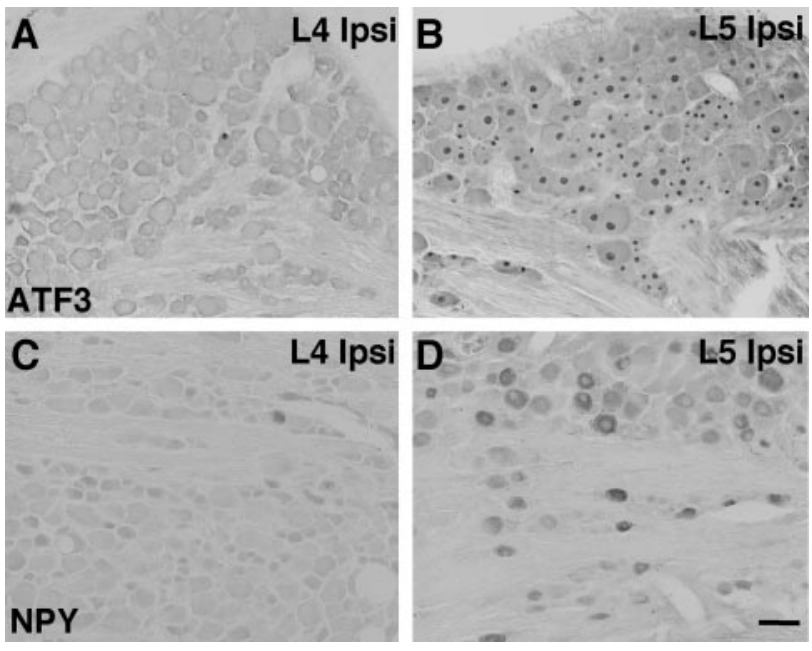

Figure 1. L4 DRG neurons are predominantly spared neurons in the L5 SNL model. Photomicrographs showing the ATF3 immunoreactivity $(A, B)$ and NPY immunoreactivity $(C, D)$ in the ipsilateral L4 and L5 DRG, respectively, at $7 \mathrm{~d}$ after L5 SNL surgery. A very small number of ATF3and NPY-IR neurons was seen in the ipsilateral L4 DRG. In contrast, increased ATF3 and NPY immunoreactivity was clearly apparent in the ipsilateral L5 DRG. Scale bar: (in D) A-D, $100 \mu \mathrm{m}$.

primary antibody for NF200 (1:400; Sigma, St. Louis, MO) were used for DAB staining. For the double immunofluorescent staining for p-p38 and NF200, GFAP, trkA, BDNF, or TRPV1, the tyramide signal amplification (PerkinElmer Life Sciences, Boston, MA) fluorescence procedures
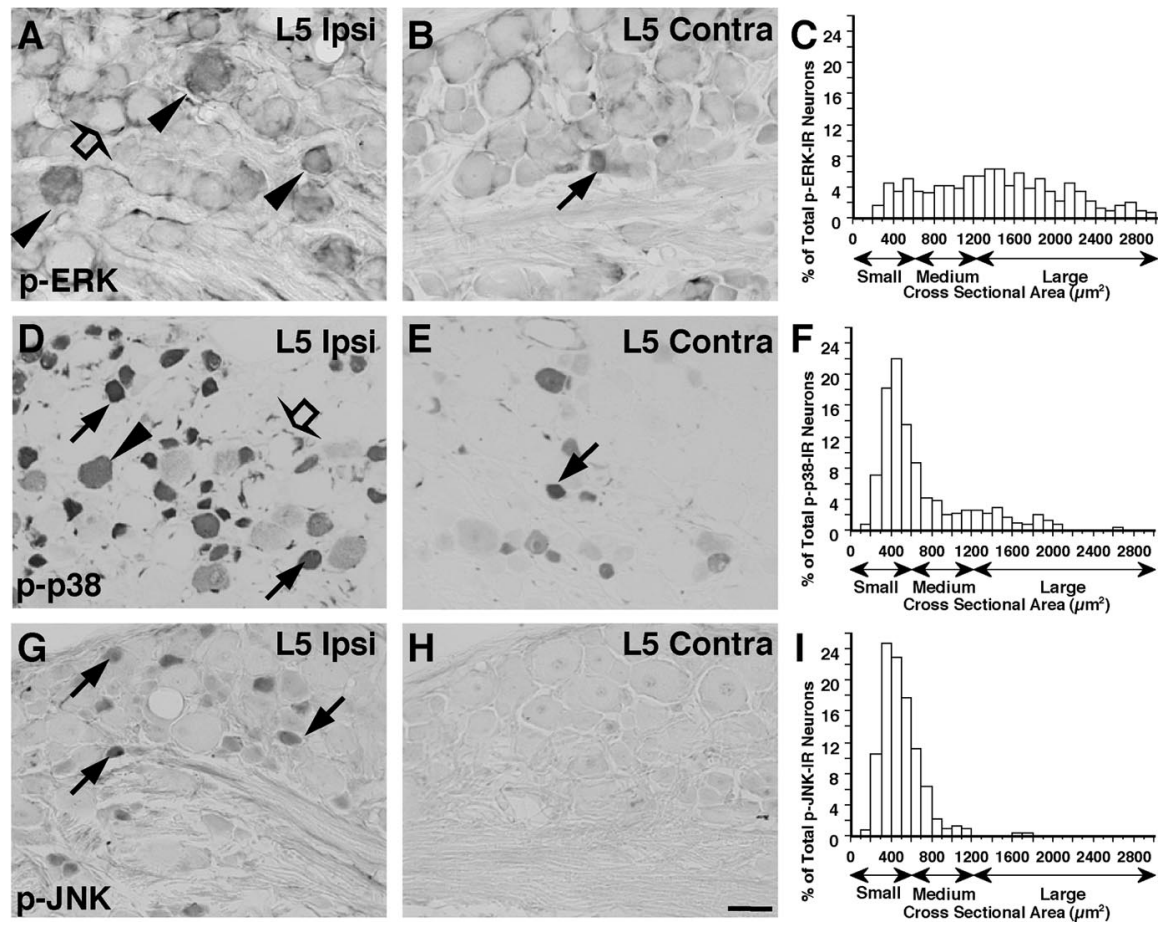

Figure 2. In the injured L5 DRG, L5 SNL induces an increase in p-ERK, p-p38, and p-JNK expression in different populations of DRG neurons and satellite glial cells. Photomicrographs show p-ERK $(A, B), \mathrm{p}$-p38 $(D, E)$, and p-JNK $(G, H)$ immunoreactivity in the ipsilateral and contralateral L5 DRG, respectively, at $7 \mathrm{~d}$ after L5 SNL surgery. The L5 SNL increased $p$-ERK and p-p38 expression in both neurons and surrounding satellite cells (open arrows) in the ipsilateral L5 DRG. The arrowheads indicate medium-sized to large neurons, whereas the arrows indicate small sensory neurons. In contrast, the L5 SNL increased p-JNK expression only in small neurons (arrows). C, F, I, Size-distribution histogram of p-ERK-IR (C), p-p38-IR $(F)$, and p-JNK-IR $(I)$ neuron profiles in the ipsilateral L 5 DRG at $7 \mathrm{~d}$ after the L5 SNL surgery. At least 300 neuron profiles with visible nuclei were counted in four to six randomly chosen sections from two rats ( $2-3$ sections/rat). The increase in p-ERK and p-JNK was seen in large and small neurons, respectively, whereas the increase in p-p38 was detected in smallto large-diameter neurons. Scale bar: (in $H$ ) $A, B, D, E, G, H, 50 \mu \mathrm{m}$.
(Michael et al., 1997; Obata et al., 2002) were used to detect staining for rabbit anti-p-p38 polyclonal antibody (1:10,000; Cell Signaling Techology) ronal profiles that showed distinctive labeling in the DRG sections. In each rat, four to six sections of the L4/5 DRG at each time point were selected randomly, and 2000-3000 profiles were counted. An average percentage of p-ERK1/2-, p-p38-, p-SAPK/JNK-, BDNF-, and tained for each animal across the different tissue sections, then the $-\mathrm{SD}$ across animals was determined. For the size-frequency histissue profiles were performed using a computerized image analysis system (NIH Image), and only neurons with clearly visible nuclei were used for quantification. To distinguish cell size-specific changes, we divided the DRG neurons into small $\left(<600 \mu \mathrm{m}^{2}\right)$, medium $\left(600-1200 \mu \mathrm{m}^{2}\right)$, At least 300 p-ERK1/2-, p-p38-, or p-SAPK/JNK-IR neuron profiles were measured in each group. Because a stereological approach was not used the actual number of cells and neurons. An assistant who was unaware of ANOVA, followed by individual post hoc comparisons (Fisher's exact st). Pairwise comparisons ( $t$ test) were used to assess differences of values between the intrathecal groups. A difference was accepted as significant if $p<0.05$.

ISHH. For the ISHH, the tissue was sectioned (16 $\mu \mathrm{m}$ thick) with a cryostat, thaw-mounted onto Vectabond (Vector Laboratories, Burlingame, CA)-coated slides, and stored at $-80^{\circ} \mathrm{C}$ until ready for use. The procedure for ISHH was basically the same as that used in previous studies (Yamanaka et al., 1999; Hashimoto et al., 2001). Briefly, the rat BDNF and TRPV1 cRNA probe corresponding to nucleotides 2273-2579 and 149-505, respectively, was prepared. The sections were treated with $10 \mu \mathrm{g} / \mathrm{ml}$ proteinase $\mathrm{K}$ in $50 \mathrm{~mm}$ Tris- $\mathrm{HCl}$ and $5 \mathrm{~mm}$ EDTA for 3 min and acetylated with $0.25 \%$ acetic anhydride in $0.1 \mathrm{~m}$ triethanolamine, then ${ }^{35} \mathrm{~S}$-labeled RNA probe $\left(5 \times 10^{6} \mathrm{cpm} / \mathrm{ml}\right)$ was placed on these sections overnight at $55^{\circ} \mathrm{C}$. Hybridized sections were rinsed in $5 \times$ SSC and 5 $\mathrm{mm}$ DTT for $30 \mathrm{~min}$ at $65^{\circ} \mathrm{C}$, washed in highstringency buffer for $30 \mathrm{~min}$ at $65^{\circ} \mathrm{C}$, and treated with $2 \mu \mathrm{g} / \mathrm{ml}$ RNase A for $30 \mathrm{~min}$ at $37^{\circ} \mathrm{C}$. Sections were rinsed, dehydrated in an ascending ethanol series, and air dried. For autoradiography, the sections were coated with NTB-3 emulsion (Eastman Kodak, Rochester, $\mathrm{NY}$ ), diluted $6: 4$ with distilled water at $45^{\circ} \mathrm{C}$, and exposed for 2 weeks in light-tight boxes at $4^{\circ} \mathrm{C}$. After development in D19 (Eastman Kodak) and fixation in $24 \%$ sodium thiosulfate, the sections were rinsed in distilled water, stained with hematoxylin-eosin, dehydrated in a graded ethanol series, cleared in xylene, and coverslipped.

Measurements of the density of silver grains over randomly selected tissue profiles were performed by a blinded assistant using the NIH Image program, in which only neuronal profiles that contained nuclei were used for quantification. At a magnification of $200 \times$ and with bright-field illumination, the upper and lower thresholds of gray level density were set such 
that only silver grains were accurately discriminated from the background in the outlined cell or tissue profile and read by the computer pixel-by-pixel. Subsequently, the area of discriminated pixels was measured and divided by the area of the outlined profile, giving a grain density for each cell or tissue profile. To reduce the risk of biased sampling of the data because of varying emulsion thickness, we used a signal/ noise $(\mathrm{S} / \mathrm{N})$ ratio for each cell in each tissue section. The $\mathrm{S} / \mathrm{N}$ ratio of an individual neuron and its cross-sectioned area, which was computed from the outlined profile, was plotted. Based on this scattergram, neurons with a grain density of 10-fold the background level or higher $(10 \leq \mathrm{S} / \mathrm{N}$ ratio $)$ were considered positively labeled for BDNF and TRPV1 mRNA. At least 250 neurons from each DRG of each rat were measured. The number of positively labeled DRG neurons was divided by the number of neuronal profiles counted in each DRG.

One-way ANOVA, followed by individual post hoc comparisons (Fisher's exact test) or pairwise comparisons ( $t$ test), was used to assess differences of values between the intrathecal groups. A difference was accepted as significant if $p<0.05$.

$R T-P C R$. For the RT-PCR, the rats were killed by decapitation under deep anesthesia at $7 \mathrm{~d}$ after surgery, and the left L4 DRG was removed and rapidly frozen with powdered dry ice and stored at $-80^{\circ} \mathrm{C}$ until ready for use. The procedure of extraction of total RNA using an RNA extraction reagent ISOGEN (Nippon Gene, Tokyo, Japan) was described in our previous study (Fukuoka et al., 2001). PCR primers for BDNF, TRPV1, and glyceraldehyde 3-phosphate dehydrogenase (GAPDH) cDNA were designed corresponding to the coding region of the genes as follows: BDNF primers, sense 5'-GGCAGGTTCGAGAGGTCTGA-3' and antisense $5^{\prime}$ CGCTGTGACCCACTCGCTAA-3'; TRPV1 primers, sense $5^{\prime}$-CCCTCCAGACAGAGACCCTA-3' and antisense 5' ${ }^{\prime}$-CGCTTCTTGCTCCTCTGCAG-3'; GAPDH primers, sense $5^{\prime}$-TGCTGGTGCTGAGTATGTCG- $3^{\prime}$ and antisense 5'-GCATGTCAGATCCACAACGG-3'. Subsequent PCR was performed in a $50 \mu$ l solution of $1 \times$ PCR buffer (PerkinElmer Life Sciences), $0.2 \mathrm{~mm}$ deoxyNTP, and 1.25 U of AmpliTaq (PerkinElmer Life Sciences) with a pair of $50 \mathrm{pmol}$ BDNF primers, 20 pmol TRPV1 primers, or 20 pmol GAPDH primers on a Perkin DNA Thermal Cycler (PerkinElmer Life Sciences), and the PCR program was $15 \mathrm{sec}$ at $94^{\circ} \mathrm{C}, 15 \mathrm{sec}$ at $57^{\circ} \mathrm{C}$, and $45 \mathrm{sec}$ at $72^{\circ} \mathrm{C}$. The intensity of stained bands was measured with a computer-assisted imaging analysis system (ATTO Densitograph, version 4.02; ATTO, Tokyo, Japan). The density of PCR product bands of BDNF, TRPV1, and GAPDH mRNAs was increased between 25 and 35 PCR cycles, depending on the number of cycles; therefore the number of PCR cycles used was 30 . The ratio of BDNF or TRPV1 to GAPDH mRNAs was considered to indicate the level of each transcript. The mRNA level was expressed as a percentage of the mRNA level in the normal control ganglia. Samples without the addition of reverse transcriptase or without the addition of RNA (negative controls) revealed no detectable product.

Data are expressed as mean $\pm \mathrm{SD}$. Differences in changes of values between the intrathecal groups were tested using one-way ANOVA, followed by individual post hoc comparisons (Fisher's exact test) or pairwise comparisons ( $t$ test). A difference was accepted as significant if $p<0.05$.
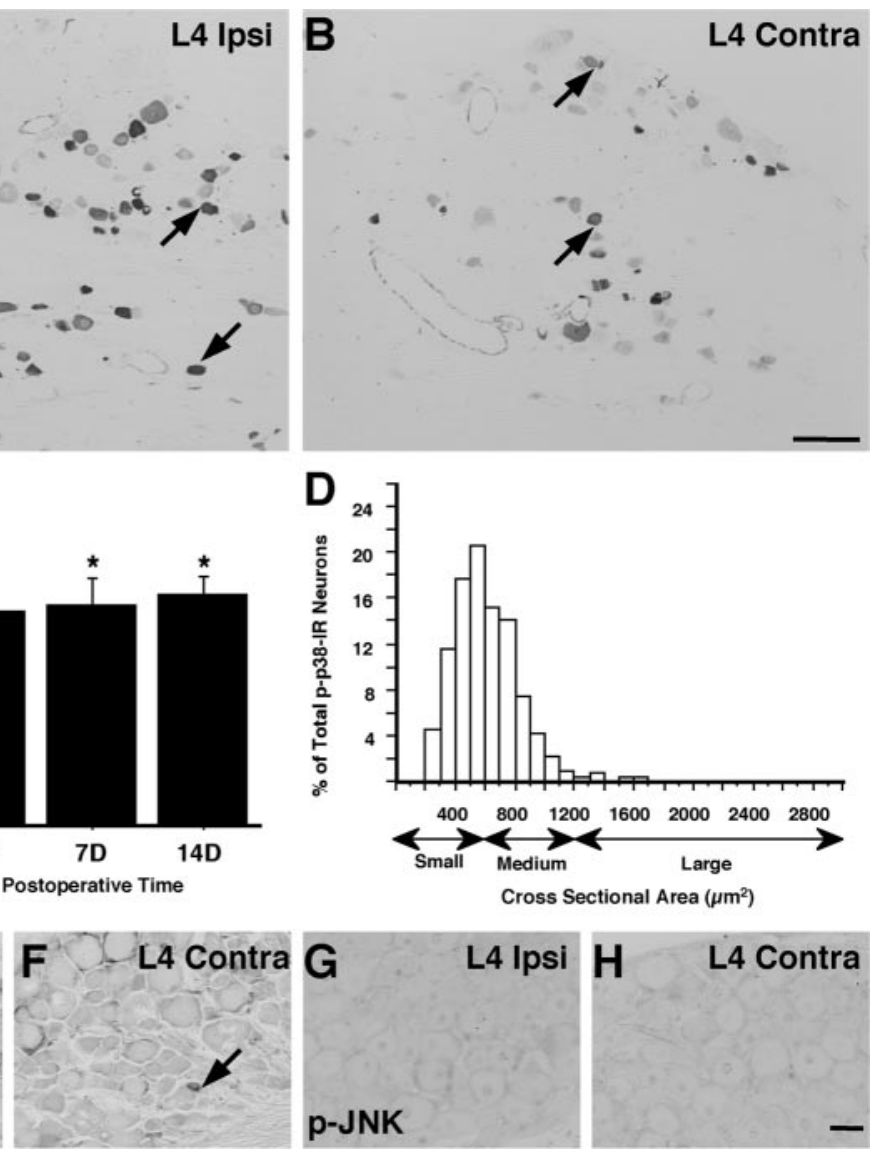

Figure 3. In the uninjured L4 DRG, L5 SNL induced a sustained increase in p-p38, but not p-ERK or p-JNK, mainly in small and medium-sized neurons. $A, B$, Photomicrographs showing p-p38 immunoreactivity in the ipsilateral $(A)$ and contralateral $(B) L$ in the ipsilateral L4DRG. C, Time course of the mean percentages of $p$-p38-IR neurons relative to the total number of neurons in the in the ipsilateral and contralateral L4 DRG, respectively, at $7 \mathrm{~d}$ after the L5 SNL surgery. The L5 SNL did not alter $p$-ERK and p-JNK expression in the ipsilateral L4 DRG. Scale bar: (in B) A, B, $100 \mu \mathrm{m}$; (in H) $E-H, 50 \mu \mathrm{m}$.

\section{Results}

Virtually all L4 DRG neurons are spared from axotomy in the L5 SNL model

To identify the axotomized sensory neurons in the L4 and L5 DRG after the L5 SNL, we examined the immunoreactivity of ATF3, which has been suggested to be a neuronal injury marker (Tsujino et al., 2000; Tsuzuki et al., 2001). ATF3 immunoreactivity was expressed exclusively in the nuclei of virtually all ipsilateral L5 DRG neurons (Fig. $1 B$ ), whereas there was only occasional ATF3 immunoreactivity in the naive and ipsilateral L4 DRG throughout the 2 week time course of the experiment (Fig. $1 A$ ). We also assessed the expression of NPY in the L4 and L5 DRG because the increase in NPY expression occurs in the axotomized medium- to large-diameter DRG neurons (Wakisaka et al., 1991; Hokfelt et al., 1994). NPY was dramatically upregulated in the large-diameter neurons in the ipsilateral L5 DRG (Fig. 1D), but there were few NPY-IR neurons in the naive and ipsilateral L4 DRG (Fig. 1C), consistent with previous studies (Fukuoka et al., 1998; Ossipov et al., 2002). There was also no evidence of an upregulation of galanin immunoreactivity in the ipsilateral L4 DRG after the L5 SNL (data not shown). These observations indicate that L4 DRG neurons are essentially uninjured in the L5 SNL model. 


\section{L5 SNL induces differential activation of MAPK in injured L5 DRG neurons}

To examine the activation of ERK, p38, and JNK in injured L5 DRG neurons, we used antiserum to the phosphorylated forms. In the ipsilateral L5 DRG, the L5 SNL induced an increase in the phosphorylation of ERK, mainly in large DRG neurons and in satellite glial cells (Fig. $2 A, B$ ), consistent with a previous study (Obata et al., 2003b). Seven days after L5 SNL surgery, 46 of 313 p-ERK-IR neurons counted (14.7\%) were small, 76 (24.3\%) were medium, and $191(61.0 \%)$ were large in size (mean \pm SD of the cross-sectional area, $1414 \pm 673 \mu \mathrm{m}^{2}$ ) (Fig. 2C). The L5 SNL also induced a sustained increase in $\mathrm{p} 38$ phosphorylation in small- to large-diameter DRG neurons and in satellite glial cells (Fig. $2 D, E$ ), as reported previously (Jin et al., 2003). Seven days after surgery, 192 of 312 p-p38-IR neurons counted $(61.5 \%)$ were small, $73(23.4 \%)$ were medium, and $47(15.1 \%)$ were large in size (mean \pm SD of the cross-sectional area, $688 \pm 441 \mu \mathrm{m}^{2}$ ) (Fig. 2F).

Furthermore, we examined the expression of $\mathrm{p}$-JNK in the injured L5 DRG. p-JNK immunoreactivity was never detected in the naive and contralateral ganglia after the lesion (Fig. $2 \mathrm{H}$ ); however, we found the activation of JNK mainly in small DRG neurons and not in satellite glial cells in the ipsilateral L5 DRG (Fig. 2G). Seven days after surgery, 241 of 315 p-JNK-IR neurons counted $(76.5 \%)$ were small, $72(22.9 \%)$ were medium, and 2 $(0.6 \%)$ were large in size (mean $\pm \mathrm{SD}$ of the cross-sectional area, $496 \pm 204 \mu \mathrm{m}^{2}$ ) (Fig. 2I). The p-JNK immunoreactivity in the ipsilateral L5 DRG was evident by $3 \mathrm{~d}$ after the L5 SNL, and the levels of p-JNK immunoreactivity persisted throughout the 2 week time course of the experiment, as did p-ERK and p-p38 immunoreactivity (data not shown).

\section{L5 SNL induces the activation of p38, but not ERK or JNK, in the uninjured L4 DRG neurons}

We first examined p-p38 immunoreactivity in the uninjured L4 DRG after L5 SNL. The number of p-p38-IR neurons in the ipsilateral L4 DRG markedly increased at $7 \mathrm{~d}$ after surgery compared with that in the naive and contralateral ganglia; the increase in p-p38 immunoreactivity was seen mainly in small and mediumsized neurons (Fig. $3 A, B$ ). There was no increase in the number of p-p38-IR satellite glial cells in the ipsilateral L4 DRG (Fig. 2 D, open arrow). The time course of change in the percentage of p-p38-IR neurons is shown in Figure 3C. In the L4 DRG of naive rats, $15.0 \pm 1.4 \%$ of the neurons were p-p38 immunoreactive. There was no significant change in the percentage of p-p38-IR neurons in the contralateral DRG (data not shown). The increase in the percentage of p-p38-IR neurons in the ipsilateral L4 DRG was first evident at $3 \mathrm{~d}$ after surgery $(25.6 \pm 3.0 \% ; n=4)$ and remained significantly elevated at $14 \mathrm{~d}$ after surgery $(27.3 \pm$ $2.4 \%$ ) compared with those of naive control rats. Seven days after L5 SNL surgery, 169 of 311 p-p38-IR neurons counted (54.3\%) were small, $137(44.1 \%)$ were medium, and $5(1.6 \%)$ were large in size (mean \pm SD of the cross-sectional area, $607 \pm 219 \mu \mathrm{m}^{2}$ ) (Fig. 3D). The size of neurons labeled for p-p38 immunoreactivity in the L4 DRG was much smaller than that in the L5 DRG $\left(688 \pm 441 \mu \mathrm{m}^{2} ; p<0.005\right)$ (Fig. $\left.2 F\right)$, indicating that L4 DRG neurons are clearly different from damaged L5 DRG neurons. The total nonphosphorylated p38 levels did not change after the L5 SNL (data not shown).

Next, to determine whether ERK and JNK activation occurs in the ipsilateral L4 DRG after L5 SNL, we assessed p-ERK and p-JNK immunoreactivity. However, there was no apparent change in p-ERK and p-JNK immunoreactivity in the ipsilateral
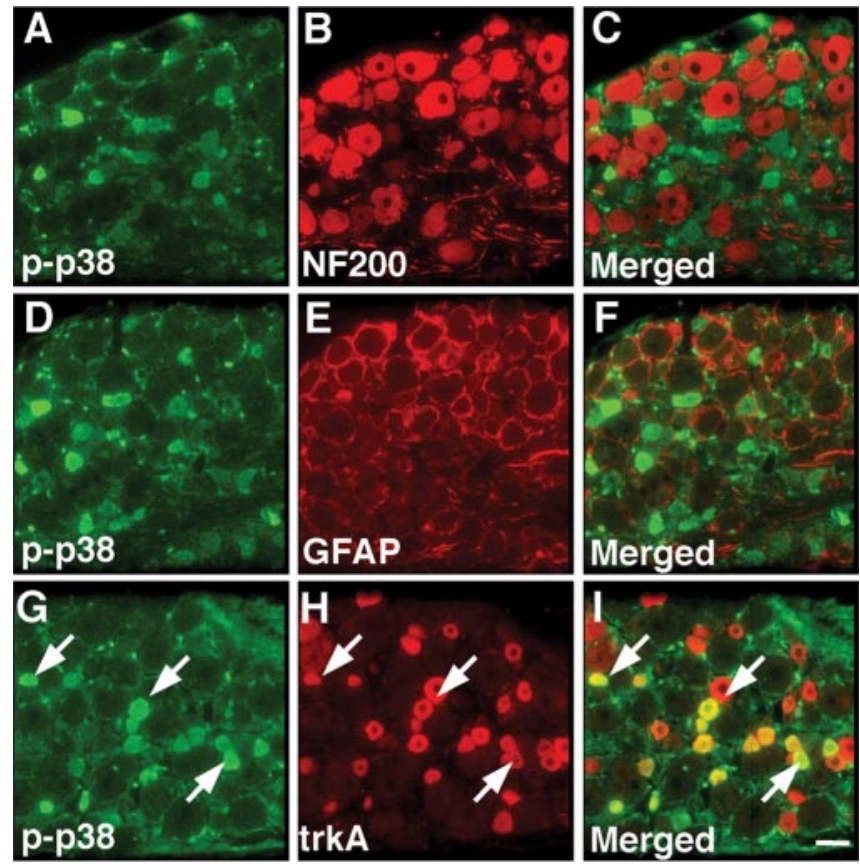

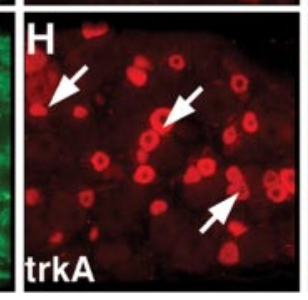

Merged

Figure 4. p38 is activated in small, presumably nociceptive DRG neurons, but not satellite glial cells in the uninjured L4 DRG after L5 SNL. Immunohistochemical colocalization of green reaction product for $\mathrm{p}-\mathrm{p} 38(A, D, G)$ and red product for $\mathrm{NF} 200(B), \operatorname{GFAP}(E)$, or trkA $(H)$ in the ipsilateral L4 DRG at $7 \mathrm{~d}$ after the L5 SNL surgery. A-C, Double staining of $p-p 38$ with NF200, a marker for myelinated A-fibers, showed no colocalization in the L4DRG neurons, indicating that p38 is predominantly activated in unmyelinated C-fiber nociceptors. $D-F$, Double labeling of p-p38 with GFAP, a marker for activated satellite glial cells, indicates that p38 is not phosphorylated in activated satellite glial cells in the L4 DRG. G-I, Double staining for p-p38 and trkA revealed a heavy colocalization in the $L 4 D R G$ neurons. The arrows indicate double-labeled neurons for p-p38 and trkA. Scale bar: (in I) A-l, $50 \mu \mathrm{m}$.

L4 DRG compared with that in the naive and contralateral ganglia (Fig. 3E-H).

In the uninjured L4 DRG, p-p38 is predominantly expressed in trkA-containing small sensory neurons

To investigate whether an increase in p-p38 in the uninjured L4 DRG after the L5 SNL is seen in a subpopulation of the DRG neurons with myelinated fibers, we examined the immunohistochemical colocalization of p-p38 and NF200, a marker for myelinated A-fibers (Michael and Priestley, 1999). The results of the colocalization study with p-p38 and NF200 in the ipsilateral L4 DRG at $7 \mathrm{~d}$ after surgery are shown in Figure $4 A-C$. p-p38- and NF200-IR neurons were clearly distinguishable, indicating that p-p38 is predominantly expressed in neurons with unmyelinated axons, the C-fibers. Next, to determine whether p38 was phosphorylated in activated satellite glial cells in the L4 DRG, colocalization of the activated satellite glial cell marker GFAP with p-p38 was performed (Fig. $4 D-F$ ). There was no staining of p-p38 in activated glial cells that stained positively for GFAP. These findings again indicate that L4 DRG neurons are primarily undamaged/spared neurons, because peripheral axotomy induces p38 activation not only in large neurons but also in GFAP-IR glial cells, as described above (Fig. 2D,F). Furthermore, we performed double immunofluorescence with p-p38 and trkA in the L4 DRG (Fig. 4G-I). p-p38 heavily colocalized with trkA at $7 \mathrm{~d}$ after surgery, indicating that these p-p38-IR neurons were NGFresponsive small sensory neurons. 

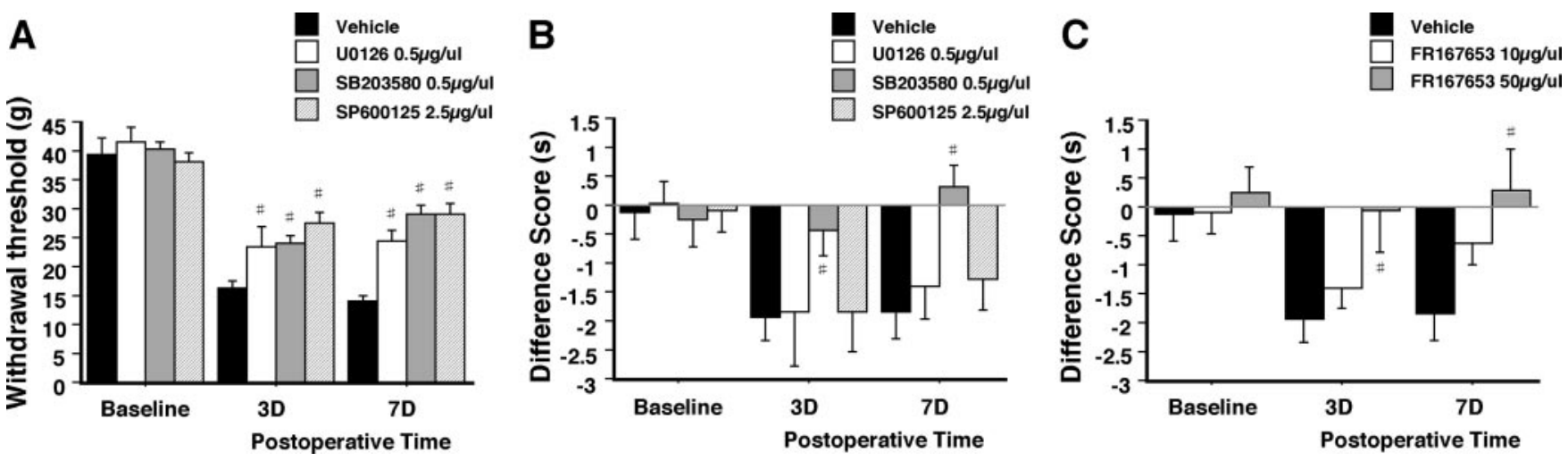

Figure 5. Effects of the MEK1/2 inhibitor U0126, the 38 inhibitors SB203580 and FR167653, or the JNK inhibitor SP600125 delivered intrathecally on L5 SNL-induced neuropathic pain behaviors. $A$, Mechanical allodynia was examined using an apparatus called a dynamic plantar aesthesiometer. Rats in the vehicle group developed mechanical hypersensitivity of the ipsilateral hindpaw at 3 and $7 \mathrm{~d}$ after surgery, but intrathecal U0126, SB203580, or SP600125 infusion significantly changed the threshold of response to mechanical stimulation. B, The difference score (latency on the operated side minus latency on the contralateral side) to the radiant heat stimuli was obtained from the same rats that received the mechanical stimuli. The mean difference score decreased and became a negative value at 3 and $7 \mathrm{~d}$ after surgery in the vehicle, U0126, and SP600125 groups, but only rats in the SB203580 group did not show a hyperalgesic response to thermal stimulation.

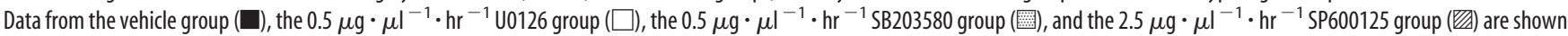
(mean \pm SEM; $n=8$ /group). ${ }^{p} p<0.05$ compared with vehicle control. C, Intrathecal administration of FR167653 also attenuated the L5 SNL-induced thermal hyperalgesia compared with the

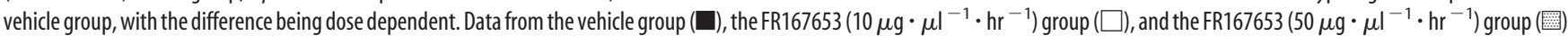
are shown (mean $\pm \mathrm{SEM} ; n=8 /$ group). ${ }^{\#} p<0.05$ compared with vehicle control.

Inhibition of $\mathrm{p} 38$ activation attenuates L5 SNL-induced thermal hyperalgesia To elucidate whether the inhibition of MAPK activation altered neuropathic pain behaviors, such as mechanical allodynia and thermal hyperalgesia, the MEK1/2 inhibitor U0126, the p38 inhibitor SB203580, or the JNK inhibitor SP600125 was delivered intrathecally before L5 SNL surgery and maintained for $7 \mathrm{~d}$ via a catheter, the tip of which was positioned close to the L4/5 DRG to target MAPK activity in the DRG. To obtain a sustained drug infusion, the drug was delivered by an osmotic pump connected to a catheter. Intrathecal administration of U0126, SB203580, or SP600125 into naive animals produced no significant changes in basal pain sensitivity (data not shown). Intrathecal U0126 $\left(0.5 \mu \mathrm{g} \cdot \mu \mathrm{l}^{-1} \cdot \mathrm{hr}^{-1}\right)$ and SB203580 $\left(0.5 \mu \mathrm{g} \cdot \mu \mathrm{l}^{-1} \cdot \mathrm{hr}^{-1}\right)$ significantly reduced the nerve injuryinduced allodynia at 3 and $7 \mathrm{~d}$ after surgery, consistent with previous reports (Ciruela et al., 2003; Jin et al., 2003; Schafers et al., 2003b) (Fig. 5A). Furthermore, we found that the JNK inhibitor SP600125 $\left(2.5 \mu \mathrm{g} \cdot \mu \mathrm{l}^{-1} \cdot \mathrm{hr}^{-1}\right)$ also inhibited mechanical hypersensitivity at 3 and $7 \mathrm{~d}$ after surgery (Fig. $5 \mathrm{~A}$ ). In contrast, rats in the U0126 and SP600125 groups did not show a significant change in thermal hyperalgesia compared with rats in the vehicle group (Fig. 5B). However, the p38 inhibitor SB203580 completely reversed the L5 SNL-induced hyperalgesia not only at $3 \mathrm{~d}$ but also at $7 \mathrm{~d}$ after surgery (Fig. $5 B$ ).

The p38 inhibitor SB203580 does not inhibit the phosphorylation of p38 but rather binds to the ATP pocket in the enzyme, thereby inhibiting its activity (Koistinaho and Koistinaho, 2002). On the other hand, FR167653 was first discovered as a potent inhibitor of tumor necrosis factor (TNF)- $\alpha$ and interleukin- $1 \beta$ production (Yamamoto et al., 1996, 1997). Recent reports have shown that FR167653 inhibits the activation of p38 MAPK by suppressing the phosphorylation of $\mathrm{p} 38$, preferentially in the $\alpha$ isoform, but not in the $\gamma$ isoform (Kawashima et al., 2001; Takahashi et al., 2001; Yoshinari et al., 2001). We therefore investigated whether not only SB203580 but also FR167653 blocks the SNL-induced thermal hyperalgesia (Fig. 5C). Intrathecal administration of FR167653 $\left(50 \mu \mathrm{g} \cdot \mu \mathrm{l}^{-1} \cdot \mathrm{hr}^{-1}\right)$ significantly reduced the L5 SNL-induced heat hypersensitivity measured at 3 and $7 \mathrm{~d}$. Rats in the FR167653 $\left(10 \mu \mathrm{g} \cdot \mu \mathrm{l}^{-1} \cdot \mathrm{hr}^{-1}\right)$ group showed a trend toward decreased heat hyperalgesia compared with the vehicle control, although there was no significant change (Fig. $5 C$ ).

\section{L5 dorsal rhizotomy did not block the SNL-induced} thermal hyperalgesia

To ascertain whether p38 activation in the uninjured L4 DRG might be involved in the development of heat hypersensitivity in the L5 SNL model, we first assessed the effects of L4 dorsal rhizotomy on pain hypersensitivity produced by L5 SNL (Fig. 6). Rats in the L5 SNL and L4 dorsal rhizotomy group showed a signifi- 

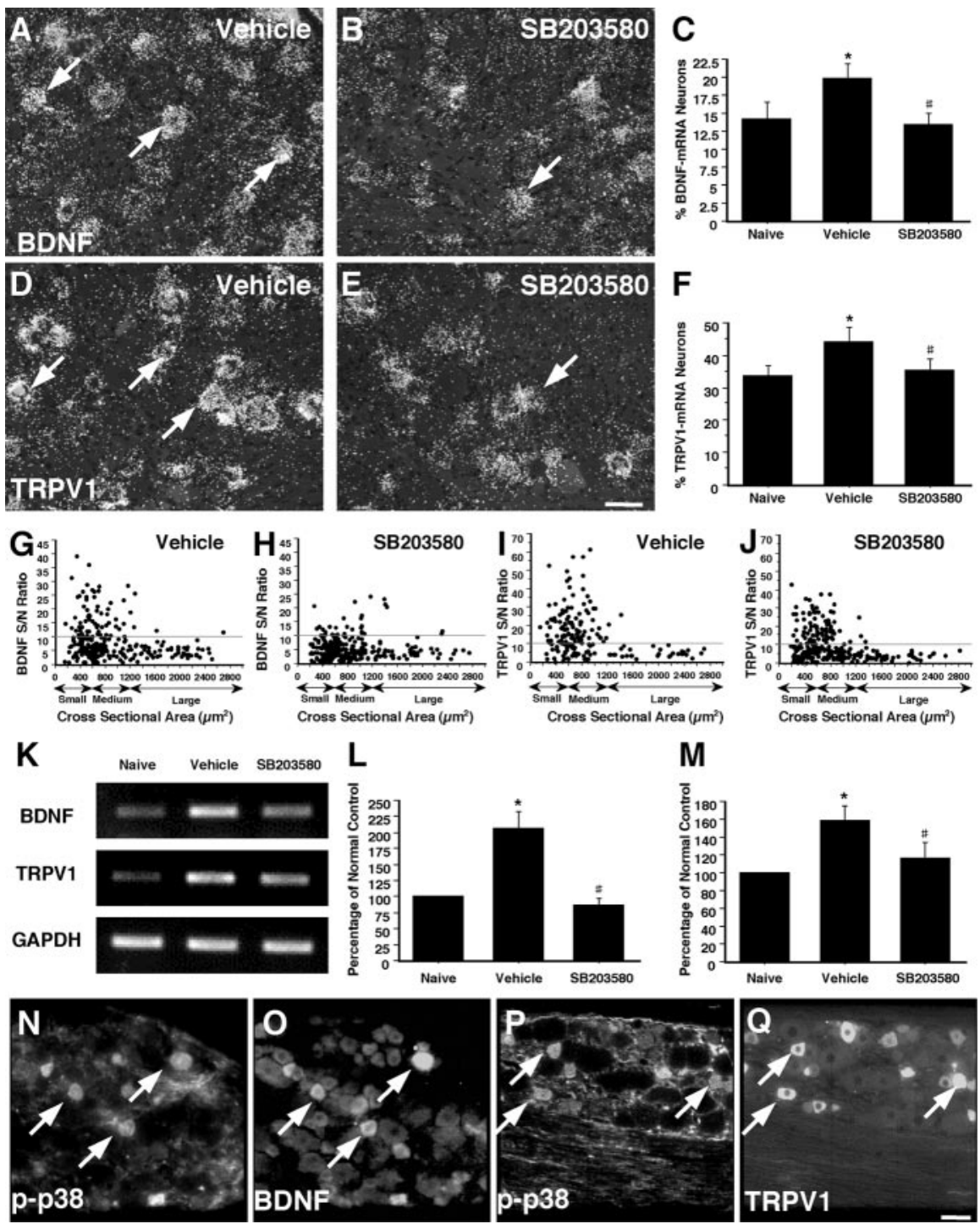

Figure 7. Effects of the $\mathrm{p} 38$ inhibitor SB203580 delivered intrathecally on L5 SNL-induced BDNF and TRPV1 expression in the uninjured $L 4$ DRG. $A, B$, Photomicrographs showing the expression of BDNF mRNA $(A, B)$ and TRPV1 mRNA $(D, E)$ in the $L 4$ DRG in the vehicle and SB203580 groups, respectively, at $7 \mathrm{~d}$ after $L 5$ SNL surgery. C, F, Quantification of the percentage of BDNF mRNA-positive ( $C$ and TRPV1 mRNA-positive ( $F$ ) neurons at $7 \mathrm{~d}$ after the L5 SNL. ${ }^{*} p<0.05$ compared with the naive control; $\# p<0.05$ compared with vehicle control. $G-J$, The scatterplot diagrams of BDNF mRNA $(G, H)$ and TRPV1 mRNA $(I, J)$ were made by plotting the individual cell profiles according to the cross-sectional area (in micrometers squared; along the $x$-axis) and the $S / N$ ratio (along the $y$-axis) in the vehicle and SB203580 groups, respectively. The dotted lines represent the borderlines between the negatively and positively labeled neurons ( $\mathrm{S} / \mathrm{N}$ ratio, 10$) . K-M$, The levels of BDNF and TRPV1 $\mathrm{mRNA}$ in the ipsilateral L4 DRG as determined by the RT-PCR technique. Gel panels show PCR products from the $L 4 D R G$ taken at $7 \mathrm{~d}$ after surgery $(K)$. The mRNA levels of $B D N F(L)$ and TRPV1 $(M)$ were expressed as a percentage of the mRNA level in the normal control ganglia (mean $\pm S D$ ). ${ }^{*} p<0.05$ compared with the naive control; ${ }^{*} p<0.05$ compared with vehicle control. $N-Q$, Double labeling for $p-p 38(N, P)$ and BDNF ( 0 ) or TRPV1 ( $Q$ ) immunoreactivity in the L4 DRG at $7 \mathrm{~d}$ after the L5 SNL. Double labeling of neurons with p-p38 and BDNF or TRPV1 was observed ( $N-Q$; arrows). Scale bar: (in $E) A, B, D, E, 50 \mu \mathrm{m}$; (in $N) N-Q, 50 \mu \mathrm{m}$.

cant change in mechanical and heat hypersensitivity compared with rats in the L5 SNL group, indicating that the L4 spinal nerve and DRG is the main route through which the impulses evoked in the periphery are transferred to the spinal dorsal horn in the L5 SNL model (Takahashi et al., 1994; Prats-Galino et al., 1999; Decosterd and Woolf, 2000). Indeed, the difference scores shifted to positive values at 7 and $14 \mathrm{~d}$ after surgery (i.e., thermal hypoalgesia). Next, we examined whether L5 dorsal rhizotomy could reverse the L5 SNL-induced mechanical and heat hypersensitivity (Fig. 6). L5 dorsal rhizotomy that was made immediately before L5 SNL prevented the development of mechanical allodynia; however, it was not able to block the SNL-induced thermal hyperalgesia at $7 \mathrm{~d}$, and also at $14 \mathrm{~d}$, after L5 SNL surgery, suggesting that the uninjured L4 DRG neurons might contribute to the development of thermal hyperalgesia. L4 or L5 dorsal rhizotomy, by itself, did not induce neuropathic pain behaviors across the testing period (data not shown).

p38 activation regulates BDNF and TRPV1 expression in the uninjured L4 DRG

Previous reports have demonstrated upregulation of BDNF and TRPV1 expression in the uninjured L4 DRG after L5 SNL surgery (Ha et al., 2001; Hudson et al., 2001; Fukuoka et al., 2002). To examine whether BDNF and TRPV1 expression in the ipsilateral L4 DRG is regulated by p38 activation, the mRNA for BDNF and TRPV1 was compared in the vehicle and SB203580 groups using ISHH (Fig. 7A-J). The p38 inhibitor SB203580 $(0.5$ $\mu \mathrm{g} \cdot \mu \mathrm{l}^{-1} \cdot \mathrm{hr}^{-1}$ ) significantly reduced the SNL-induced increase in BDNF mRNA, which was seen mainly in small and medium-sized neurons (Fig. $7 G, H$ ). In the L4 DRG of naive rats, $14.4 \pm 2.2 \%$ of the neurons were BDNF mRNA-positive neurons. The percentage of BDNF mRNApositive neurons in the vehicle group at $7 \mathrm{~d}$ after the SNL was markedly increased to $20.0 \pm 1.9 \%$, but SB203580 was able to block the effects induced by the SNL $(13.5 \pm 1.4 \% ; n=4)$ (Fig. 7C). Furthermore, SB203580 suppressed the SNLinduced elevation of TRPV1 mRNA, which was also observed mainly in smallto medium-diameter sensory neurons (Fig. $7 D, E, I, J)$. In the 44 DRG of naive rats, $34.1 \pm 2.7 \%$ of the neurons were TRPV1 mRNA-positive neurons. The number of neurons labeled for TRPV1 mRNA in the vehicle group $7 \mathrm{~d}$ after the lesion was clearly increased (44.5 $\pm 4.1 \%$; $n=4$ ), but the increase in the percentage of TRPV1 mRNA-positive neurons was blocked significantly by the p38 inhibitor $(35.6 \pm 3.4 \%)$ (Fig. $7 F)$. The changes in BDNF and TRPV1 mRNA/protein were also confirmed by RT-PCR and immunohistochemistry (Fig. $7 K-M$, Table 1$)$. The levels of BDNF and TRPV1 mRNA/protein in the vehicle group at $7 \mathrm{~d}$ after surgery were significantly greater than the preoperative value, but these increases were prevented by SB203580.

Next, to determine whether the p-p38-IR neurons and BDNFor TRPV1-expressing neurons belonged to the same subset of DRG neurons, we performed double labeling for p-p38 and BDNF or TRPV1 in the ipsilateral L4 DRG (Fig. 7N-Q). Seven days after surgery, both BDNF and TRPV1 were detected in $\sim 80 \%$ of p-p38-labeled neurons. 
Table 1. Quantification of the percentage of BDNF- and TRPV1-IR neurons in the ipsilateral L4 DRG at $7 \mathrm{~d}$ after the L5 SNL ( $n=4 /$ group)

\begin{tabular}{lllll}
\hline & & \multicolumn{3}{l}{ Intrathecal injection } \\
\cline { 3 - 5 } & Naive & Vehicle & SB203580 & Anti-NGF \\
\hline BDNF & $11.7 \pm 0.9 \%$ & $18.5 \pm 2.5 \%^{*}$ & $11.3 \pm 2.8 \%^{* *}$ & $12.8 \pm 4.0 \%^{* *}$ \\
TRPV1 & $33.0 \pm 2.4 \%$ & $39.9 \pm 0.5 \%^{*}$ & $31.6 \pm 2.0 \%^{* *}$ & $34.0 \pm 3.2 \% \%^{* *}$
\end{tabular}

${ }^{*} p<0.05$ compared with the naive control; ${ }^{* *} p<0.05$ compared with vehicle control.

NGF, p38 activation, and BDNF and TRPV1 expression in the uninjured L4 DRG

NGF injection in a peripheral target induces p38 activation in small DRG neurons (Ji et al., 2002; Delcroix et al., 2003), and NGF also increases the production of BDNF and TRPV1 mRNA through trkA receptors (Apfel et al., 1996; Winston et al., 2001). To elucidate whether alterations in endogenous NGF can trigger changes in L5 SNL-induced thermal hyperalgesia, activation of p38, and, furthermore, upregulation of BDNF and TRPV1 in the ipsilateral L4 DRG, we administered anti-NGF into the intrathecal space via a catheter, the tip of which was positioned close to the L4/5 DRG. Intrathecal anti-NGF application $\left(1 \mu \mathrm{g} \cdot \mu \mathrm{l}^{-1} \cdot \mathrm{hr}^{-1}\right)$ reversed the development of thermal hyperalgesia at 3 and $7 \mathrm{~d}$ after surgery (Fig. 8A). Next, we assessed the effect of anti-NGF on L5 SNLinduced neurochemical changes in the L4 DRG. L5 SNL induced a substantial increase in the percentage of p-p38-IR neurons in the vehicle group at $7 \mathrm{~d}$ after surgery (Fig. $8 \mathrm{~B}$ ), but this increase was prevented by anti-NGF (Fig. $8 C$ ). Furthermore, anti-NGF significantly reduced the L5 SNL-induced increase in the percentage of BDNF mRNA- and TRPV1 mRNA-positive neurons in the L4 DRG at $7 \mathrm{~d}$ after surgery (Fig. 8D,E). The decreases in BDNF and TRPV1 mRNA/protein were also confirmed by RTPCR and immunohistochemistry (Fig. 8F, Table 1). SP and CGRP expression in the ipsilateral L4 DRG was also decreased after intrathecal SB203580 or anti-NGF infusion (data not shown).

NGF is a neurotrophic factor that is retrogradely transported to the DRG from the periphery. Therefore, we aimed to block the NGF being transported to the L4 DRG using local application of anti-NGF antibody $\left(1 \mu \mathrm{g} \cdot \mu \mathrm{l}^{-1} \cdot \mathrm{hr}^{-1}\right)$ on the surface of the L4 spinal nerve. Thermal hyperalgesia was apparent in the vehicle group at 3 and $7 \mathrm{~d}$ after surgery, whereas the anti-NGF group showed the significant reversal of heat hypersensitivity at $7 \mathrm{~d}$ after surgery (Fig. 8G). Furthermore, local anti-NGF application significantly reduced the L5 SNL-induced increase in BDNF and TRPV1 protein in the L4 DRG at $7 \mathrm{~d}$ after surgery (Table 2).

\section{Discussion}

In this study, we have shown that in the injured L5 DRG, the L5 SNL induced an increase in the phosphorylation of ERK, p38, and JNK in different populations of DRG neurons. Intrathecal ERK, p38, and JNK inhibitor infusions reversed the L5 SNL-induced mechanical allodynia. In contrast, in the uninjured L4 DRG, the L5 SNL induced the activation of p38, but not ERK and JNK, in trkA-expressing small- to medium-diameter neurons. Only p38 inhibitor treatment attenuated the L5 SNL-induced thermal hyperalgesia. L5 dorsal rhizotomy prevented the L5 SNL-induced mechanical allodynia but not thermal hyperalgesia. Furthermore, both p38 inhibitor and anti-NGF application blocked the SNL-induced increase in BDNF and TRPV1 expression in the L4 DRG.
A
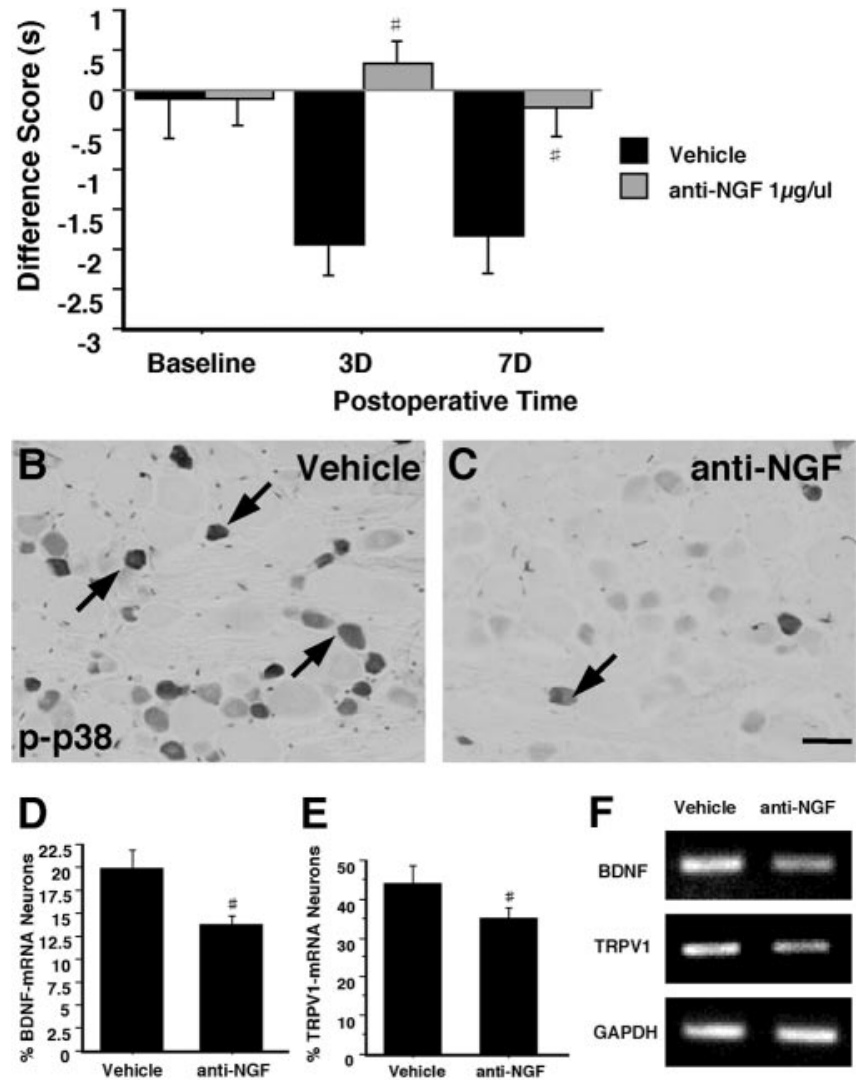

G

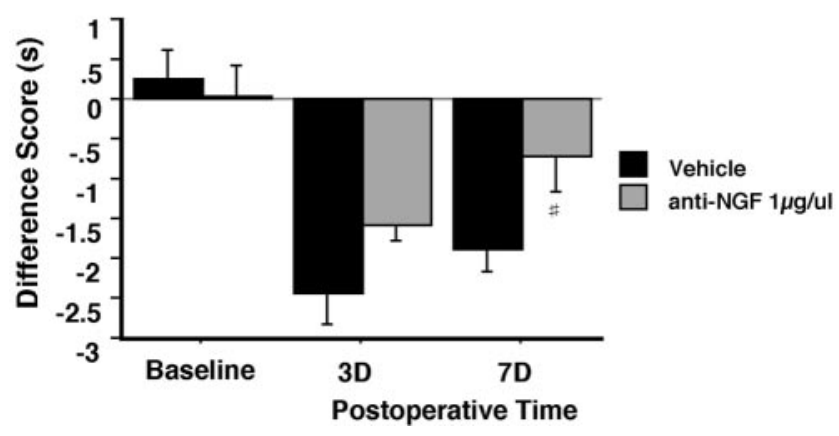

Figure 8. $A-F$, Effects of intrathecal infusion of anti-NGF on the $L 5 S N L$-induced heat hypersensitivity and increase in p-p38, BDNF, and TRPV1 expression in the L4 DRG. $A$, Bar graph showing the difference scores to the radiant heat stimuli. Data from the vehicle group ( $\square$ ) and

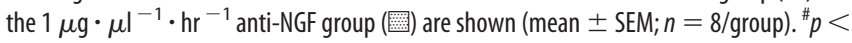
0.05 compared with vehicle control. $B, C$, Photomicrographs showing p-p38 immunoreactivity in the L4 DRG in the vehicle $(B)$ and anti-NGF ( $C$ ) groups at $7 \mathrm{~d}$ after the L5 SNL surgery. D, E, Quantification of the percentage of BDNF mRNA-positive $(D)$ and TRPV1 mRNA-positive $(E)$ neurons at $7 \mathrm{~d}$ after the L5 SNL. ${ }^{*} p<0.05$ compared with the vehicle group. $F$, The levels of BDNF and TRPV1 mRNA in the ipsilateral L4 DRG as determined by the RT-PCR technique. Gel panels show PCR products from the L4 DRG taken at $7 \mathrm{~d}$ after surgery. $G$, Effects of local application of anti-NGF on the L5 SNL-induced heat hypersensitivity. A bar graph showing the difference scores to the radiant heat stimuli is shown. Data from the vehicle group ( $\square$ ) and the $1 \mu \mathrm{g} \cdot \mu^{-1} \cdot \mathrm{hr}^{-1}$ anti-NGF group (眷) are shown (mean $\pm \mathrm{SEM} ; n=7 /$ group). ${ }^{\#} p<0.05$ compared with vehicle control. Scale bar, (in $C) B, C, 50 \mu \mathrm{m}$.

p38 activation in the adjacent intact L4 DRG neurons and Wallerian degeneration

Recently, electrophysiological experiments have suggested that the uninjured primary afferents are functionally important in the maintenance of neuropathic pain (Ali et al., 1999; Michaelis et al., 
Table 2. Quantification of the percentage of BDNF- and TRPV1-IR neurons in the ipsilateral L4 DRG at $7 \mathrm{~d}$ after the L5 SNL ( $n=3 /$ group)

\begin{tabular}{lll}
\hline & \multicolumn{2}{l}{ Local application } \\
\cline { 2 - 3 } & Vehicle & Anti-NGF \\
\hline BDNF & $19.3 \pm 2.3 \%$ & $15.8 \pm 2.2 \% *$ \\
TRPV1 & $40.1 \pm 0.5 \%$ & $35.7 \pm 1.6 \% *$ \\
\hline
\end{tabular}

${ }^{*} p<0.05$ compared with the vehicle group.

2000; Wu et al., 2001). In addition, changes in the molecular phenotype of undamaged DRG neurons after partial nerve injury have been reported. For example, the expression of SP, CGRP, BDNF, and TRPV1 increases in the spared neurons (Fukuoka and Noguchi, 2002; Fukuoka et al., 2002; Obata et al., 2003a, 2004). In contrast, recent reports demonstrated that peripheral nerve injury induces the activation of p38 in axotomized DRG neurons (Jin et al., 2003; Schafers et al., 2003b). Furthermore, Kim et al. (2002) showed p38 activation in small sensory neurons after CCI; however, they did not identify whether these neurons were injured or spared. In the present study, using the L5 SNL model, we demonstrated for the first time that p38, but not ERK and JNK, was activated in the adjacent intact DRG, mainly trkAcontaining small neurons. We also found that anti-NGF blocked the L5 SNL-induced p38 activation in the L4 DRG.

Wallerian degeneration, after nerve lesion, leads to an increase in cytokines and growth factors (Myers et al., 1996; Ramer et al., 1997; Sommer and Schafers, 1998; Cui et al., 2000; Shamash et al., 2002). Among them, NGF is suggested to be a major contributor to the persistent pain states, and NGF injection in a peripheral target induces p38 activation in small DRG neurons (Ji et al., 2002). Therefore, these findings suggest that after L5 SNL, NGF, synthesized and released in the degenerative nerve fibers, acts on nearby sensory fibers along the course of the nerve and induces p38 activation in the adjacent intact L4 DRG neurons. However, considering that not only p38 but also ERK and JNK could be activated by NGF (Averil et al., 2001; Mamet et al., 2003) and, furthermore, that local application of anti-NGF did not completely block the L5 SNL-induced thermal hyperalgesia, there is a possibility that other cytokines and growth factors, such as TNF- $\alpha$, also may be involved in selective p38 activation in the L4 DRG (Schafers et al., 2003a).

\section{BDNF and TRPV1 expression in adjacent intact L4 DRG neurons and thermal hyperalgesia}

An enhanced transport of NGF to the DRG leads to an increase in the production of SP, CGRP, BDNF, and TRPV1 expression. In the present study, not only the p38 inhibitor but also anti-NGF reduced SNL-induced thermal hyperalgesia and upregulation of BDNF and TRPV1 expression in the intact L4 DRG. Furthermore, L5 dorsal rhizotomy did not prevent the development of heat hypersensitivity. Therefore, we believe that p38 activation by NGF in intact L4 DRG neurons participates in thermal hyperalgesia by regulating BDNF and TRPV1 expression after the L5 SNL.

BDNF that is synthesized in the DRG is transported to the central terminals of the primary afferents in the dorsal horn, is released, and acts on the trkB receptor on second-order sensory neurons (Kafitz et al., 1999; Mannion et al., 1999; Thompson et al., 1999). Several studies have reported that intrathecal injection of trkB-IgG and anti-BDNF prevented the development of thermal hyperalgesia in the peripheral inflammation and neuropathic pain models (Kerr et al., 1999; Fukuoka et al., 2001; Groth and Aanonsen, 2002), although the action of BDNF in the dorsal horn is likely to be complex (Pezet et al., 2002; Malcangio and Lessmann, 2003). In contrast, TRPV1, one of the transducer proteins, can generate depolarizing currents in response to noxious thermal stimuli. Our data are very consistent with previous electrophysiological and gene knock-out studies of TRPV1 function (i.e., TRPV1 is required for peripheral sensitization to noxious thermal but not mechanical stimuli) (Caterina et al., 2000; Davis et al., 2000). The present study showed the upregulation in TRPV1 mRNA/protein in the uninjured DRG, although several studies have demonstrated an increase in the TRPV1 protein but not in its mRNA, after peripheral inflammation (Tohda et al., 2001; Ji et al., 2002). The reasons for this discrepancy are not clear, but other reports have shown that inflammation and/or NGF increased TRPV1 mRNA in adult DRG neurons (Winston et al., 2001; Amaya et al., 2003).

\section{MAPK activation in the injured L5 DRG neurons and mechanical allodynia}

Nerve injury-induced pain has been closely linked to activation of spontaneous and persistent abnormal discharge from ectopic foci, primarily observed in amyloid $\beta$ (Devor, 1991; Koltzenburg et al., 1994; Devor and Seltzer, 1999), and A-fibers have been suggested to drive central sensitization (Scholz and Woolf, 2002). The present study demonstrated that in the injured L5 DRG, most of the p-ERK-IR neurons and a subpopulation of p-p38-IR neurons were large in size and that the ERK and p38 inhibitors reversed the L5 SNL-induced mechanical allodynia. Furthermore, L5 dorsal rhizotomy prevented the development of mechanical allodynia, as reported previously (Yoon et al., 1996; Sukhotinsky et al., 2004). These observations support the possibility that large-diameter A-fibers mediate mechanical allodynia, whereas nociceptive C-fibers mediate thermal hyperalgesia (Ossipov et al., 1999; Pan et al., 2003). A recent report showed that nerve injury-induced tactile but not thermal hypersensitivity is mediated by upregulated NPY via large fibers projecting to the gracile nucleus (Ossipov et al., 2002). Therefore, we speculate that MAPK activation in injured large DRG neurons participates in allodynia development by regulating NPY expression after the L5 SNL.

It is well known that withdrawal of growth factors activates the JNK pathway, which could underlie the negative regulation. In addition, JNK is also activated by positive factors such as the cytokine TNF- $\alpha$ in cultured sensory neurons (Pollock et al., 2002). An unexpected finding in the present study was that the JNK inhibitor SP600125 inhibited SNL-induced mechanical allodynia, whereas the increase in p-JNK was found predominantly in injured small neurons. Several studies revealed spontaneous activity only in A-fiber afferents but not in injured C-fiber afferents (Boucher et al., 2000; Liu et al., 2000); however, other reports showed a crucial role for small sensory neurons in the development of mechanical allodynia (Nichols et al., 1999; Porreca et al., 1999). Therefore, we believe that no matter what the cell size, the activation of MAPK in the injured L5 DRG plays an important role in allodynia development after nerve injury by increasing gene transcription, although the mechanisms of MAPK activation in different populations of L5 DRG neurons are not clearly characterized at this point. Alternatively, we cannot exclude the possibility that p38 activation in the uninjured L4 DRG contributes to the development of mechanical allodynia.

MAPK signaling in the spinal cord and pain hypersensitivity Sheen and Chung (1993) demonstrated that L5 dorsal rhizotomy attenuated L5 SNL-induced thermal hyperalgesia. Furthermore, 
others reported that L5 dorsal rhizotomy did not attenuate L5 SNL-induced mechanical allodynia and that L5 dorsal rhizotomy itself can lead to pain behaviors (Colburn et al., 1999; Tabo et al., 1999; Eschenfelder et al., 2000; Li et al., 2000; Sheth et al., 2002). Therefore, various methodological factors, such as the type of injury, the extent of the lesion, the distance of the injury from the DRG, time courses, and behavioral testing techniques, may contribute to the discrepancy between our observations and those of others.

A number of pathophysiological changes in the spinal cord and the higher CNS might occur and participate in producing neuropathic pain. Indeed, recent studies have demonstrated that the activation of MAPK in dorsal horn neurons and glial cells in the spinal cord contributes to persistent inflammatory and neuropathic pain (Ji, 2004; Obata and Noguchi, 2004). For example, the reduction in neuropathic pain by $\mathrm{p} 38$ inhibition occurs before the appearance of p38 activation in DRG neurons (Jin et al., 2003). Therefore, the effects of MAPK inhibitors on pathological pain could be mediated by the inhibition of MAPK activation, not only in the DRG, but also in the spinal cord. However, these pathological changes in the CNS are secondary to pathophysiological changes in first-order sensory neurons and require altered afferent input for their maintenance (Devor and Seltzer, 1999). We believe that the differential activation of MAPK in injured and intact primary afferents is likely to have a substantial role in the pathogenesis of neuropathic pain after partial nerve injury, and MAPK pathways in nociceptors may be potential targets for the development of novel analgesics.

\section{References}

Aley KO, Martin A, McMahon T, Mok J, Levine JD, Messing RO (2001) Nociceptor sensitization by extracellular signal-regulated kinases. J Neurosci 21:6933-6939.

Ali Z, Ringkamp M, Hartke TV, Chien HF, Flavahan NA, Campbell JN, Meyer RA (1999) Uninjured C-fiber nociceptors develop spontaneous activity and alpha-adrenergic sensitivity following L6 spinal nerve ligation in monkey. J Neurophysiol 81:455-466.

Amaya F, Oh-hashi K, Naruse Y, Iijima N, Ueda M, Shimosato G, Tominaga M, Tanaka Y, Tanaka M (2003) Local inflammation increases vanilloid receptor 1 expression within distinct subgroups of DRG neurons. Brain Res 963:190-196.

Apfel SC, Wright DE, Wiideman AM, Dormia C, Snider WD, Kessler JA (1996) Nerve growth factor regulates the expression of brain-derived neurotrophic factor mRNA in the peripheral nervous system. Mol Cell Neurosci 7:134-142.

Averill S, Delcroix JD, Michael GJ, Tomlinson DR, Fernyhough P, Priestley JV (2001) Nerve growth factor modulates the activation status and fast axonal transport of erk $1 / 2$ in adult nociceptive neurones. Mol Cell Neurosci 18:183-196.

Bennett GJ, Xie YK (1988) A peripheral mononeuropathy in rat that produces disorders of pain sensation like those seen in man. Pain 33:87-107.

Boucher TJ, Okuse K, Bennett DL, Munson JB, Wood JN, McMahon SB (2000) Potent analgesic effects of GDNF in neuropathic pain states. Science 290:124-127.

Caterina MJ, Leffler A, Malmberg AB, Martin WJ, Trafton J, Petersen-Zeitz KR, Koltzenburg M, Basbaum AI, Julius D (2000) Impaired nociception and pain sensation in mice lacking the capsaicin receptor. Science 288:306-313.

Ciruela A, Dixon AK, Bramwell S, Gonzalez MI, Pinnock RD, Lee K (2003) Identification of MEK1 as a novel target for the treatment of neuropathic pain. Br J Pharmacol 138:751-756.

Colburn RW, Rickman AJ, DeLeo JA (1999) The effect of site and type of nerve injury on spinal glial activation and neuropathic pain behavior. Exp Neurol 157:289-304.

Cui JG, Holmin S, Mathiesen T, Meyerson BA, Linderoth B (2000) Possible role of inflammatory mediators in tactile hypersensitivity in rat models of mononeuropathy. Pain 88:239-248.

Dai Y, Iwata K, Fukuoka T, Kondo E, Tokunaga A, Yamanaka H, Tachibana
T, Liu Y, Noguchi K (2002) Phosphorylation of extracellular signalregulated kinase in primary afferent neurons by noxious stimuli and its involvement in peripheral sensitization. J Neurosci 22:7737-7745.

Davis JB, Gray J, Gunthorpe MJ, Hatcher JP, Davey PT, Overend P, Harries MH, Latcham J, Clapham C, Atkinson K, Hughes SA, Rance K, Grau E, Harper AJ, Pugh PL, Rogers DC, Bingham S, Randall A, Sheardown SA (2000) Vanilloid receptor-1 is essential for inflammatory thermal hyperalgesia. Nature 405:183-187.

Decosterd I, Woolf CJ (2000) Spared nerve injury: an animal model of persistent peripheral neuropathic pain. Pain 87:149-158.

Delcroix JD, Valletta JS, Wu C, Hunt SJ, Kowal AS, Mobley WC (2003) NGF signaling in sensory neurons: evidence that early endosomes carry NGF retrograde signals. Neuron 39:69-84.

Devor M (1991) Neuropathic pain and injured nerve: peripheral mechanisms. Br Med Bull 47:619-630.

Devor M, Seltzer Z (1999) Pathophysiology of damaged nerves in reaction to chronic pain. In: Textbook of pain (Wall PD, Melzack R, eds), pp 129-164. London: Churchill Livingstone.

Dina OA, McCarter GC, de Coupade C, Levine JD (2003) Role of the sensory neuron cytoskeleton in second messenger signaling for inflammatory pain. Neuron 39:613-624.

Eschenfelder S, Habler HJ, Janig W (2000) Dorsal root section elicits signs of neuropathic pain rather than reversing them in rats with L5 spinal nerve injury. Pain 87:213-219.

Fukuoka T, Noguchi K (2002) Contribution of the spared primary afferent neurons to the pathomechanisms of neuropathic pain. Mol Neurobiol 26:57-67.

Fukuoka T, Tokunaga A, Kondo E, Miki K, Tachibana T, Noguchi K (1998) Change in mRNAs for neuropeptides and the $\mathrm{GABA}(\mathrm{A})$ receptor in dorsal root ganglion neurons in a rat experimental neuropathic pain model. Pain 78:13-26.

Fukuoka T, Kondo E, Dai Y, Hashimoto N, Noguchi K (2001) Brain-derived neurotrophic factor increases in the uninjured dorsal root ganglion neurons in selective spinal nerve ligation model. J Neurosci 21:4891-4900.

Fukuoka T, Tokunaga A, Tachibana T, Dai Y, Yamanaka H, Noguchi K (2002) VR1, but not P2X(3), increases in the spared L4 DRG in rats with L5 spinal nerve ligation. Pain 99:111-120.

Gold MS (2000) Spinal nerve ligation: what to blame for the pain and why. Pain 84:117-120.

Groth R, Aanonsen L (2002) Spinal brain-derived neurotrophic factor (BDNF) produces hyperalgesia in normal mice while antisense directed against either BDNF or trkB, prevent inflammation-induced hyperalgesia. Pain 100:171-181.

Ha SO, Kim JK, Hong HS, Kim DS, Cho HJ (2001) Expression of brainderived neurotrophic factor in rat dorsal root ganglia, spinal cord and gracile nuclei in experimental models of neuropathic pain. Neuroscience 107:301-309.

Hashimoto N, Yamanaka H, Fukuoka T, Dai Y, Obata K, Mashimo T, Noguchi K (2001) Expression of HGF and cMet in the peripheral nervous system of adult rats following sciatic nerve injury. NeuroReport 12:1403-1407.

Hokfelt T, Zhang X, Wiesenfeld-Hallin Z (1994) Messenger plasticity in primary sensory neurons following axotomy and its functional implications. Trends Neurosci 17:22-30.

Hudson LJ, Bevan S, Wotherspoon G, Gentry C, Fox A, Winter J (2001) VR1 protein expression increases in undamaged DRG neurons after partial nerve injury. Eur J Neurosci 13:2105-2114.

Ji RR (2004) Mitogen-activated protein kinases as potential targets for pain killers. Curr Opin Investig Drugs 5:71-75.

Ji RR, Samad TA, Jin SX, Schmoll R, Woolf CJ (2002) p38 MAPK activation by NGF in primary sensory neurons after inflammation increases TRPV1 levels and maintains heat hyperalgesia. Neuron 36:57-68.

Jin SX, Zhuang ZY, Woolf CJ, Ji RR (2003) p38 mitogen-activated protein kinase is activated after a spinal nerve ligation in spinal cord microglia and dorsal root ganglion neurons and contributes to the generation of neuropathic pain. J Neurosci 23:4017-4022.

Kafitz KW, Rose CR, Thoenen H, Konnerth A (1999) Neurotrophin-evoked rapid excitation through TrkB receptors. Nature 401:918-921.

Kalmar B, Greensmith L, Malcangio M, McMahon SB, Csermely P, Burnstock G (2003) The effect of treatment with BRX-220, a co-inducer of heat shock proteins, on sensory fibers of the rat following peripheral nerve injury. Exp Neurol 184:636-647. 
Kawashima Y, Takeyoshi I, Otani Y, Koibuchi Y, Yoshinari D, Koyama T, Kobayashi M, Matsumoto K, Morishita Y (2001) FR167653 attenuates ischemia and reperfusion injury of the rat lung with suppressing p38 mitogen-activated protein kinase. J Heart Lung Transplant 20:568-574.

Kenney AM, Kocsis JD (1998) Peripheral axotomy induces long-term c-Jun amino-terminal kinase- 1 activation and activator protein-1 binding activity by c-Jun and junD in adult rat dorsal root ganglia in vivo. J Neurosci 18:1318-1328.

Kerr BJ, Bradbury EJ, Bennett DL, Trivedi PM, Dassan P, French J, Shelton DB, McMahon SB, Thompson SW (1999) Brain-derived neurotrophic factor modulates nociceptive sensory inputs and NMDA-evoked responses in the rat spinal cord. J Neurosci 19:5138-5148.

Kim SH, Chung JM (1992) An experimental model for peripheral neuropathy produced by segmental spinal nerve ligation in the rat. Pain 50:355-363.

Kim SY, Bae JC, Kim JY, Lee HL, Lee KM, Kim DS, Cho HJ (2002) Activation of p38 MAP kinase in the rat dorsal root ganglia and spinal cord following peripheral inflammation and nerve injury. NeuroReport 13:2483-2486.

Koistinaho M, Koistinaho J (2002) Role of p38 and p44/42 mitogenactivated protein kinases in microglia. Glia 40:175-183.

Koltzenburg M, Torebjork HE, Wahren LK (1994) Nociceptor modulated central sensitization causes mechanical hyperalgesia in acute chemogenic and chronic neuropathic pain. Brain 117:579-591.

Lever I, Cunningham J, Grist J, Yip PK, Malcangio M (2003) Release of BDNF and GABA in the dorsal horn of neuropathic rats. Eur J Neurosci 18:1169-1174.

Lewis TS, Shapiro PS, Ahn NG (1998) Signal transduction through MAP kinase cascades. Adv Cancer Res 74:49-139.

Li Y, Dorsi MJ, Meyer RA, Belzberg AJ (2000) Mechanical hyperalgesia after an L5 spinal nerve lesion in the rat is not dependent on input from injured nerve fibers. Pain 85:493-502.

Liu CN, Wall PD, Ben-Dor E, Michaelis M, Amir R, Devor M (2000) Tactile allodynia in the absence of C-fiber activation: altered firing properties of DRG neurons following spinal nerve injury. Pain 85:503-521.

Ma W, Bisby MA (1998a) Increase of calcitonin gene-related peptide immunoreactivity in the axonal fibers of the gracile nuclei of adult and aged rats after complete and partial sciatic nerve injuries. Exp Neurol 152:137-149.

Ma W, Bisby MA (1998b) Increase of preprotachykinin mRNA and substance $\mathrm{P}$ immunoreactivity in spared dorsal root ganglion neurons following partial sciatic nerve injury. Eur J Neurosci 10:2388-2399.

Ma C, Shu Y, Zheng Z, Chen Y, Yao H, Greenquist KW, White FA, LaMotte RH (2003) Similar electrophysiological changes in axotomized and neighboring intact dorsal root ganglion neurons. J Neurophysiol 89:1588-1602.

Malcangio M, Lessmann V (2003) A common thread for pain and memory synapses? Brain-derived neurotrophic factor and trkB receptors. Trends Pharmacol Sci 24:116-121.

Mamet J, Lazdunski M, Voilley N (2003) How nerve growth factor drives physiological and inflammatory expressions of acid-sensing ion channel 3 in sensory neurons. J Biol Chem 278:48907-48913.

Mannion RJ, Costigan M, Decosterd I, Amaya F, Ma QP, Holstege JC, Ji RR, Acheson A, Lindsay RM, Wilkinson GA, Woolf CJ (1999) Neurotrophins: peripherally and centrally acting modulators of tactile stimulusinduced inflammatory pain hypersensitivity. Proc Natl Acad Sci USA 96:9385-9390.

Michael GJ, Priestley JV (1999) Differential expression of the mRNA for the vanilloid receptor subtype 1 in cells of the adult rat dorsal root and nodose ganglia and its downregulation by axotomy. J Neurosci 19:1844-1854.

Michael GJ, Averill S, Nitkunan A, Rattray M, Bennett DL, Yan Q, Priestley JV (1997) Nerve growth factor treatment increases brain-derived neurotrophic factor selectively in TrkA-expressing dorsal root ganglion cells and in their central terminations within the spinal cord. J Neurosci 17:8476-8490.

Michaelis M, Liu X, Janig W (2000) Axotomized and intact muscle afferents but no skin afferents develop ongoing discharges of dorsal root ganglion origin after peripheral nerve lesion. J Neurosci 20:2742-2748.

Myers RR, Heckman HM, Rodriguez M (1996) Reduced hyperalgesia in nerve-injured WLD mice: relationship to nerve fiber phagocytosis, axonal degeneration, and regeneration in normal mice. Exp Neurol 141:94-101.

Nichols ML, Allen BJ, Rogers SD, Ghilardi JR, Honore P, Luger NM, Finke MP, Li J, Lappi DA, Simone DA, Mantyh PW (1999) Transmission of chronic nociception by spinal neurons expressing the substance P receptor. Science 286:1558-1561.

Noguchi K, Kawai Y, Fukuoka T, Senba E, Miki K (1995) Substance P induced by peripheral nerve injury in primary afferent sensory neurons and its effect on dorsal column nucleus neurons. J Neurosci 15:7633-7643.

Obata K, Noguchi K (2004) MAPK activation in nociceptive neurons and pain hypersensitivity. Life Sci 74:2643-2653.

Obata K, Tsujino H, Yamanaka H, Dai Y, Fukuoka T, Hashimoto N, Yonenobu K, Yoshikawa H, Noguchi K (2002) Expression of neurotrophic factors in the dorsal root ganglion in a rat model of lumbar disc herniation. Pain 99:121-132.

Obata K, Yamanaka H, Fukuoka T, Dai Y, Tokunaga A, Hashimoto N, Yoshikawa H, Noguchi K (2003a) Contribution of injured and uninjured DRG neurons to pain behavior and the changes in gene expression following chronic constriction injury of the sciatic nerve in rats. Pain 101:65-77.

Obata K, Yamanaka H, Dai Y, Tachibana T, Fukuoka T, Tokunaga A, Yoshikawa H, Noguchi K (2003b) Differential activation of extracellular signal-regulated protein kinase in primary afferent neurons regulates brain-derived neurotrophic factor expression after peripheral inflammation and nerve injury. J Neurosci 23:4117-4126.

Obata K, Yamanaka H, Dai Y, Mizushima T, Fukuoka T, Tokunaga A, Yoshikawa H, Noguchi K (2004) Contribution of degeneration of motor and sensory fibers to pain behavior and the changes in neurotrophic factors in rat dorsal root ganglion. Exp Neurol 188:149-160.

Ossipov MH, Bian D, Malan Jr TP, Lai J, Porreca F (1999) Lack of involvement of capsaicin-sensitive primary afferents in nerve-ligation injury induced tactile allodynia in rats. Pain 79:127-133.

Ossipov MH, Zhang ET, Carvajal C, Gardell L, Quirion R, Dumont Y, Lai J, Porreca F (2002) Selective mediation of nerve injury-induced tactile hypersensitivity by neuropeptide Y. J Neurosci 22:9858-9867.

Pan HL, Khan GM, Alloway KD, Chen SR (2003) Resiniferatoxin induces paradoxical changes in thermal and mechanical sensitivities in rats: mechanism of action. J Neurosci 23:2911-2919.

Pezet S, Malcangio M, McMahon SB (2002) BDNF: a neuromodulator in nociceptive pathways? Brain Res Brain Res Rev 40:240-249.

Pollock J, McFarlane SM, Connell MC, Zehavi U, Vandenabeele P, MacEwan DJ, Scott RH (2002) TNF-alpha receptors simultaneously activate $\mathrm{Ca}^{2+}$ mobilisation and stress kinases in cultured sensory neurones. Neuropharmacology 42:93-106.

Porreca F, Lai J, Bian D, Wegert S, Ossipov MH, Eglen RM, Kassotakis L, Novakovic S, Rabert DK, Sangameswaran L, Hunter JC (1999) A comparison of the potential role of the tetrodotoxin-insensitive sodium channels, PN3/SNS and NaN/SNS2, in rat models of chronic pain. Proc Nat Acad Sci USA 96:7640-7644.

Prats-Galino A, Puigdellivol-Sanchez A, Ruano-Gil D, Molander C (1999) Representations of hindlimb digits in rat dorsal root ganglia. J Comp Neurol 408:137-145.

Ramer MS, French GD, Bisby MA (1997) Wallerian degeneration is required for both neuropathic pain and sympathetic sprouting into the DRG. Pain 72:71-78.

Schafers M, Geis C, Svensson CI, Luo ZD, Sommer C (2003a) Selective increase of tumour necrosis factor-alpha in injured and spared myelinated primary afferents after chronic constrictive injury of rat sciatic nerve. Eur J Neurosci 17:791-804.

Schafers M, Svensson CI, Sommer C, Sorkin LS (2003b) Tumor necrosis factor- $\alpha$ induces mechanical allodynia after spinal nerve ligation by activation of p38 MAPK in primary sensory neurons. J Neurosci 23:2517-2521.

Schafers M, Lee DH, Brors D, Yaksh TL, Sorkin LS (2003c) Increased sensitivity of injured and adjacent uninjured rat primary sensory neurons to exogenous tumor necrosis factor- $\alpha$ after spinal nerve ligation. J Neurosci 23:3028-3038.

Scholz J, Woolf CJ (2002) Can we conquer pain? Nat Neurosci [Suppl] 5:1062-1067.

Seltzer Z, Dubner R, Shir Y (1990) A novel behavioral model of neuropathic pain disorders produced in rats by partial sciatic nerve injury. Pain 43:205-218.

Shamash S, Reichert F, Rotshenker S (2002) The cytokine network of Wallerian degeneration: tumor necrosis factor- $\alpha$, interleukin- $\alpha$, and interleukin-1 $\beta$. J Neurosci 22:3052-3060. 
Sheen K, Chung JM (1993) Signs of neuropathic pain depend on signals from injured nerve fibers in a rat model. Brain Res 610:62-68.

Sheth RN, Dorsi MJ, Li Y, Murinson BB, Belzberg AJ, Griffin JW, Meyer RA (2002) Mechanical hyperalgesia after an L5 ventral rhizotomy or an L5 ganglionectomy in the rat. Pain 96:63-72.

Sommer C, Schafers M (1998) Painful mononeuropathy in C57BL/Wld mice with delayed wallerian degeneration: differential effects of cytokine production and nerve regeneration on thermal and mechanical hypersensitivity. Brain Res 784:154-162.

Sukhotinsky I, Ben-Dor E, Raber P, Devor M (2004) Key role of the dorsal root ganglion in neuropathic tactile hypersensibility. Eur J Pain 8:135-143.

Tabo E, Jinks SL, Eisele Jr JH, Carstens E (1999) Behavioral manifestations of neuropathic pain and mechanical allodynia, and changes in spinal dorsal horn neurons, following L4-L6 dorsal root constriction in rats. Pain 80:503-520.

Takahashi S, Keto Y, Fujita T, Uchiyama T, Yamamoto A (2001) FR167653, a p38 mitogen-activated protein kinase inhibitor, prevents Helicobacter pylori-induced gastritis in Mongolian gerbils. J Pharmacol Exp Ther 296:48-56.

Takahashi Y, Nakajima Y, Sakamoto T (1994) Dermatome mapping in the rat hindlimb by electrical stimulation of the spinal nerves. Neurosci Lett 168:85-88.

Thompson SW, Bennett DL, Kerr BJ, Bradbury EJ, McMahon SB (1999) Brain-derived neurotrophic factor is an endogenous modulator of nociceptive responses in the spinal cord. Proc Natl Acad Sci USA 96:7714-7718.

Tohda C, Sasaki M, Konemura T, Sasamura T, Itoh M, Kuraishi Y (2001) Axonal transport of VR1 capsaicin receptor mRNA in primary afferents and its participation in inflammation-induced increase in capsaicin sensitivity. J Neurochem 76:1628-1635.

Tsujino H, Kondo E, Fukuoka T, Dai Y, Tokunaga A, Miki K, Yonenobu K, Ochi T, Noguchi K (2000) Activating transcription factor 3 (ATF3) induction by axotomy in sensory and motoneurons: a novel neuronal marker of nerve injury. Mol Cell Neurosci 15:170-182.

Tsuzuki K, Kondo E, Fukuoka T, Yi D, Tsujino H, Sakagami M, Noguchi K
(2001) Differential regulation of P2X(3) mRNA expression by peripheral nerve injury in intact and injured neurons in the rat sensory ganglia. Pain 91:351-360.

Wakisaka S, Kajander KC, Bennett GJ (1991) Increased neuropeptide Y (NPY)-like immunoreactivity in rat sensory neurons following peripheral axotomy. Neurosci Lett 124:200-203.

Widmann C, Gibson S, Jarpe MB, Johnson GL (1999) Mitogen-activated protein kinase: conservation of a three-kinase module from yeast to human. Physiol Rev 79:143-180.

Winston J, Toma H, Shenoy M, Pasricha PJ (2001) Nerve growth factor regulates VR-1 mRNA levels in cultures of adult dorsal root ganglion neurons. Pain 89:181-186.

Wu G, Ringkamp M, Hartke TV, Murinson BB, Campbell JN, Griffin JW, Meyer RA (2001) Early onset of spontaneous activity in uninjured C-fiber nociceptors after injury to neighboring nerve fibers. J Neurosci 21:RC140(1-5).

Yamamoto N, Sakai F, Yamazaki H, Nakahara K, Okuhara M (1996) Effect of FR167653, a cytokine suppressive agent, on endotoxin-induced disseminated intravascular coagulation. Eur J Pharmacol 314:137-142.

Yamamoto N, Sakai F, Yamazaki H, Sato N, Nakahara K, Okuhara M (1997) FR167653, a dual inhibitor of interleukin-1 and tumor necrosis factoralpha, ameliorates endotoxin-induced shock. Eur J Pharmacol 327:169-174

Yamanaka H, He X, Matsumoto K, Shiosaka S, Yoshida S (1999) Protease $\mathrm{M} /$ neurosin mRNA is expressed in mature oligodendrocytes. Brain Res Mol Brain Res 71:217-224.

Yoon YW, Na HS, Chung JM (1996) Contributions of injured and intact afferents to neuropathic pain in an experimental rat model. Pain 64:27-36.

Yoshinari D, Takeyoshi I, Koibuchi Y, Matsumoto K, Kawashima Y, Koyama T, Ohwada S, Morishita Y (2001) Effects of a dual inhibitor of tumor necrosis factor-alpha and interleukin-1 on lipopolysaccharide-induced lung injury in rats: involvement of the p38 mitogen-activated protein kinase pathway. Crit Care Med 29:628-634. 